\title{
Continuous measurements of greenhouse gases and atmospheric oxygen at the Namib Desert Atmospheric Observatory
}

\author{
E. J. Morgan ${ }^{1}$, J. V. Lavrič ${ }^{1}$, T. Seifert ${ }^{1}$, T. Chicoine ${ }^{2}$, A. Day ${ }^{2}$, J. Gomez ${ }^{2}$, R. Logan ${ }^{2}$, J. Sack ${ }^{2}$, T. Shuuya ${ }^{2}$, \\ E. G. Uushona ${ }^{2}$, K. Vincent ${ }^{2}$, U. Schultz ${ }^{1}$, E.-G. Brunke ${ }^{3}$, C. Labuschagne ${ }^{3}$, R. L. Thompson ${ }^{1}{ }^{,}$, S. Schmidt ${ }^{1}$, \\ A. C. Manning ${ }^{1, * *}$, and M. Heimann ${ }^{1}$ \\ ${ }^{1}$ Department of Biogeochemical Systems, Max Planck Institute for Biogeochemistry, Jena, Germany \\ ${ }^{2}$ Gobabeb Research and Training Centre, Gobabeb, Namibia \\ ${ }^{3}$ South African Weather Service, Stellenbosch, South Africa \\ *now at: Norwegian Institute for Air Research, Kjeller, Norway \\ ** now at: Centre for Ocean and Atmospheric Sciences, School of Environmental Sciences, University of East Anglia, \\ Norwich, UK
}

Correspondence to: E. J. Morgan (emorgan@bgc-jena.mpg.de)

Received: 5 December 2014 - Published in Atmos. Meas. Tech. Discuss.: 4 February 2015

Revised: 30 April 2015 - Accepted: 4 May 2015 - Published: 1 June 2015

\begin{abstract}
A new coastal background site has been established for observations of greenhouse gases (GHGs) in the central Namib Desert at Gobabeb, Namibia. The location of the site was chosen to provide observations for a datapoor region in the global sampling network for GHGs. Semi-automated continuous measurements of carbon dioxide, methane, nitrous oxide, carbon monoxide, atmospheric oxygen, and basic meteorology are made at a height of $21 \mathrm{~m}$ a.g.l., $50 \mathrm{~km}$ from the coast at the northern border of the Namib Sand Sea. Atmospheric oxygen is measured with a differential fuel cell analyzer (DFCA). Carbon dioxide and methane are measured with an early-model cavity ring-down spectrometer (CRDS); nitrous oxide and carbon monoxide are measured with an off-axis integrated cavity output spectrometer (OA-ICOS). Instrument-specific water corrections are employed for both the CRDS and OA-ICOS instruments in lieu of drying. The performance and measurement uncertainties are discussed in detail. As the station is located in a remote desert environment, there are some particular challenges, namely fine dust, high diurnal temperature variability, and minimal infrastructure. The gas handling system and calibration scheme were tailored to best fit the conditions of the site. The CRDS and DFCA provide data of acceptable quality when base requirements for operation are met, specifically adequate temperature control in the laboratory and regular supply of electricity. In the case of the OA-ICOS in-
\end{abstract}

strument, performance is significantly improved through the implementation of a drift correction through frequent measurements of a reference cylinder.

\section{Introduction}

\subsection{Background and motivation}

Due to their major role in global change and the climate system, time series of atmospheric greenhouse gases (GHGs) are a cornerstone of earth system science. Since the atmosphere is generally well mixed, the gradients and spatial variability of GHGs and other trace species can be quite small, necessitating high-quality, accurate, and precise measurements.

The Southern Hemisphere is underrepresented relative to the Northern Hemisphere in the various sampling programs and networks of ground-based stations that make continuous measurements of GHGs (Tans et al., 1996; Rödenbeck et al., 2003; Marquis and Tans, 2012). Coverage is particularly poor in Africa, which complicates efforts to monitor the variations and emissions of GHGs from developing economies, biomass burning, and the terrestrial biosphere (Valentini et al., 2014). 
In this paper, we discuss the configuration and performance of a new station constructed in 2012 at a near-coastal background site at Gobabeb (GAW station ID "NMB"), Namibia, here referred to as the Namib Desert Atmospheric Observatory (NDAO). Surface flask samples have been taken near Gobabeb since 1997 as part of the US National Oceanic and Atmospheric Administration Earth System Research Laboratory Global Monitoring Division (NOAA ESRL GMD) Carbon Cycle Cooperative Global Air Sampling Network. The NMB site is $\sim 3 \mathrm{~km}$ from NDAO. The goals of this project are to expand the ground-based station network in Africa and to use the time series as a topdown perspective on regional biogeochemical cycling and surface-atmosphere exchange of GHGs. The particular focus of the project at a regional level is on the influence of biomass burning and coastal upwelling on GHG budgets. As the site receives air largely free from anthropogenic influences, it is representative of both the terrestrial and the marine background (Fig. 1). The main quantities measured at the observatory are carbon dioxide, methane, nitrous oxide, carbon monoxide, and atmospheric oxygen.

Absorption spectrometers featuring high-finesse optical cavities are proving to be a highly sensitive and userfriendly approach to measuring GHGs and are being widely adopted by the GHG measurement community (Paldus and Kachanov, 2005; Andrews et al., 2014). Commercial analyzers using the cavity ring-down spectroscopy (CRDS) and off-axis integrated cavity output spectroscopy techniques can now be purchased to measure all of the major non-synthetic greenhouse gases. While there are a fair number of reports on using such analyzers to measure $\mathrm{CO}_{2}, \mathrm{CH}_{4}$, and the tracer CO (Chen et al., 2010, 2013; Winderlich et al., 2010; Flowers et al., 2012; Zellweger et al., 2012; O'Shea et al., 2013; Rella et al., 2013), there are few assessments of such analyzers for $\mathrm{N}_{2} \mathrm{O}$, particularly from the field. Given that the natural variability of this gas in the atmosphere is quite small - consider that the seasonal cycle of $\mathrm{N}_{2} \mathrm{O}$ is typically less than 1 ppb in the lower troposphere (Jiang et al., 2007; Park et al., 2012) - the potential for off-axis integrated cavity output spectrometer (OA-ICOS) instruments to greatly increase our understanding of this powerful GHG is quite high.

Atmospheric oxygen can be used as a top-down constraint on the carbon cycle, since the major biogeochemical processes that consume or produce carbon dioxide on the global scale also consume or produce oxygen, such as respiration, photosynthesis, or combustion (Keeling and Shertz, 1992; Keeling and Manning, 2014). Since both $\mathrm{CO}_{2}$ and $\mathrm{O}_{2}$ are conservative tracers, the composition of air masses affected by these processes conform to the stoichiometry of these reactions. The stoichiometry of marine respiration and photosynthesis is not preserved after surface-atmosphere exchange, however, as the ratio of $\mathrm{O}_{2}$ to $\mathrm{CO}_{2}$ is altered by the slower equilibration of $\mathrm{CO}_{2}$ with the atmosphere due to the carbonate equilibrium system. Furthermore, as the world's oceans are not a long-term sink or source of $\mathrm{O}_{2}$, but are a sink for $\mathrm{CO}_{2}$, measurements of atmospheric oxygen can be used to constrain the marine uptake of $\mathrm{CO}_{2}$ (Keeling et al., 1996, 1998b; Stephens et al., 1998). The success of efforts to use atmospheric oxygen to quantify the global carbon cycle is dependent primarily on the availability of data, since coverage is lower for $\mathrm{O}_{2}$ than for $\mathrm{CO}_{2}$ (Manning and Keeling, 2006; Rödenbeck et al., 2008). As oxygen is a major constituent of the atmosphere, measuring small changes against the large background is technically challenging but feasible with several methods, including mass spectrometry, paramagnetic analyzers, gas chromatography, vacuum ultraviolet absorption, and fuel cell techniques (Keeling et al., 1998a; Bender et al., 1994; Tohjima, 2000; Manning et al., 1999; Stephens et al., 2003, 2007).

\subsection{Site description}

The Namib Desert is one of the driest areas on Earth, with annual precipitation usually less than $25 \mathrm{~mm} \mathrm{yr}^{-1}$, and consecutive years without rain are not unusual (Hutchinson, 1995). A distinctive feature of the area is the common occurrence of fog (60-200 days $\left.\mathrm{yr}^{-1}\right)$, a result of the nearby cold waters of the Benguela current; fog is a larger source of moisture than rainfall to the region (Shanyengana et al., 2002; Lancaster et al., 1984; Olivier and Stockton, 1989). The Köppen-Geiger climate classification is BWh (sometimes BWn, "mild desert") or BWk ("cold desert") (Kottek et al., 2006). The Namib Desert extends $\sim 2000 \mathrm{~km}$ along the coast and some $150 \mathrm{~km}$ inland where it terminates at the Great Escarpment. The biomes bordering the Namib are classified as xeric shrublands, drylands, or savannas (Olson et al., 2001).

$\mathrm{NDAO}$ is located at Gobabeb $\left(23.563^{\circ} \mathrm{S} ; 15.046^{\circ} \mathrm{E}\right)$, in the Erongo region, $\sim 600 \mathrm{~m}$ from Gobabeb Research and Training Centre (GRTC), a desert research station. The station is situated at an elevation of $408 \mathrm{~m}$ above sea level, $\sim 50 \mathrm{~km}$ from the coast, along the Kuiseb River, an ephemeral river which demarcates the northern margin of the Namib Sand Sea from a gravel plain region to the north. After years with heavier rains, sparse vegetation appears in the Sand Sea. Likewise periodic greening of the gravel plains region is not uncommon. There are some trees and vegetation along the riverbed, though much of it is dead or dormant; otherwise the region is mostly barren. All of the facilities at Gobabeb are solar powered, although there is a backup generator which runs occasionally when there is fog or the load on the system is too high. Day-to-day maintenance is performed by GRTC personnel. 

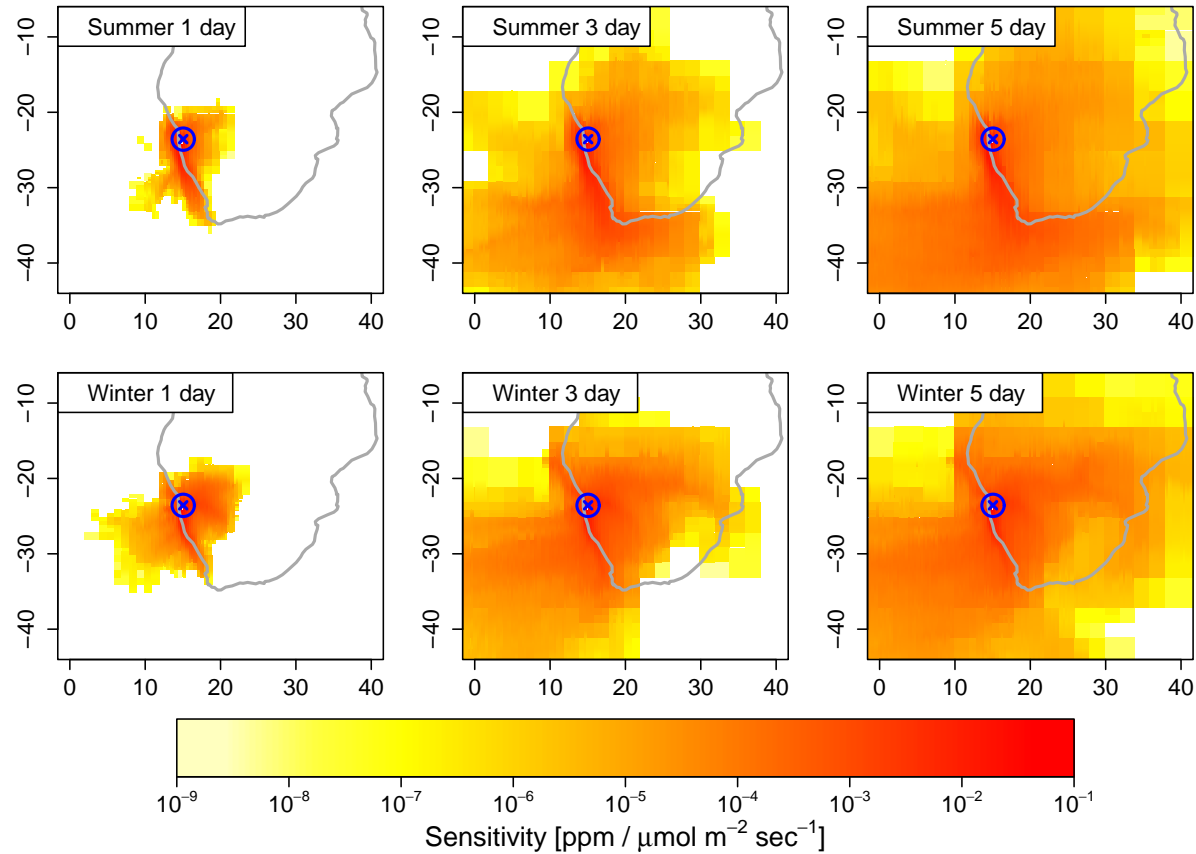

Figure 1. Average integrated footprints for NDAO during 2012-2013, using the Stochastic Time-Inverted Lagrangian Transport (STILT) model (Lin et al., 2003), driven by European Centre for Medium-Range Numerical Weather Prediction (ECMWF) meteorological fields on a $0.25^{\circ} \times 0.25^{\circ}$ grid. The domain chosen to run the model was $5^{\circ} \mathrm{N}$ to $-45^{\circ} \mathrm{S},-30^{\circ} \mathrm{W}$ to $40^{\circ}$ E. Average austral summer $($ NovemberFebruary) footprints are shown in the top row and average austral winter (June-September) footprints are shown in the bottom row, integrated over 1, 3, and 5 days. The pixel size increases in distance from NDAO due to the dynamic grid resolution of the model.

\section{Methods}

\subsection{Overview of the measurement system}

The top of an aluminum $21 \mathrm{~m}$ mast serves as the basis for all atmospheric observations at the observatory. Each of the three main instruments and the flask sampler has its own dedicated sample line. The intakes of the sample lines are each protected from suspended material and precipitation with a custom inlet. The inlet is mushroom shaped and allows for the flow-through of air, such that sample air is drawn from underneath the cap of the inlet, through a $5 \mu \mathrm{m}$ polyester filter, and then a portion is siphoned into the main sampling line. From the top of the mast to the outer wall of the container the air sampling lines are $12 \mathrm{~mm}$ SERTOflex tubing.

Large volume ( $5 \mathrm{~L} \mathrm{~min}^{-1}$ ) pumps run continuously to pull sample air down from the tower. Inside the container, sample lines (stainless steel tubing with $1 / 8$ " outer diameter) pull a smaller volume of air with a lower flow rate from the larger diameter tubing running up the tower via a $\mathrm{T}$ junction. Buffer volumes of $7 \mathrm{~L}$ are located upstream of the large pumps to minimize pressure fluctuations. Three lines of sample air pass through cool $\left(4^{\circ} \mathrm{C}\right)$ water traps filled with glass beads and cryotraps $\left(-80^{\circ} \mathrm{C}\right)$ also containing glass beads. All water traps are made from electropolished stainless steel. Sample air then is routed to the main instruments: an Oxzilla FC-II differential fuel cell analyzer (DFCA), mea- suring atmospheric oxygen (Sable Systems International, Las Vegas, NV, USA), a Picarro ESP-1000 cavity ring-down spectrometer measuring $\mathrm{CH}_{4}$ and $\mathrm{CO}_{2}$, (Picarro Inc, Santa Clara, CA, USA), and a Los Gatos $\mathrm{N}_{2} \mathrm{O} / \mathrm{CO}-23 \mathrm{~d}$ cavityenhanced absorption spectrometer measuring $\mathrm{N}_{2} \mathrm{O}$ and $\mathrm{CO}$ (Los Gatos Research Inc, Mountain View, CA, USA). Downstream of the T-junctions, the flow rates are slightly different between instruments, reflecting their different requirements for gas supply: flows are between 90 and $95 \mathrm{~mL} \mathrm{~min}^{-1}$ for the DFCA, between 150 and $210 \mathrm{~mL} \mathrm{~min}^{-1}$ for the CRDS, and between 110 and $220 \mathrm{~mL} \mathrm{~min}^{-1}$ for the OA-ICOS. The larger range for the latter two instruments is given because flow and sample line pressures gradually decline in between filter replacements due to the very fine dust present at the site.

A complete diagram of the instrument system can be seen in Fig. 2, and a part list is presented in Table 1. Four-port two-position valves, determined to have no cross-port leakage, are used to switch between reference gas streams and the air sample stream. Small membrane pumps are used to maintain sample flow during measurements of reference gases, so that sample air does not sit stagnate in the lines and so that no additional purge is necessary upon the completion of a reference cycle. The entire system is under automatic control, using a custom program written in LabVIEW. The LabVIEW system also serves as the data recorder for the meteorological instrumentation and the diagnostic sensors inside the laboratory. Data are logged at an interval of $1 \mathrm{~s}$; data generated at 


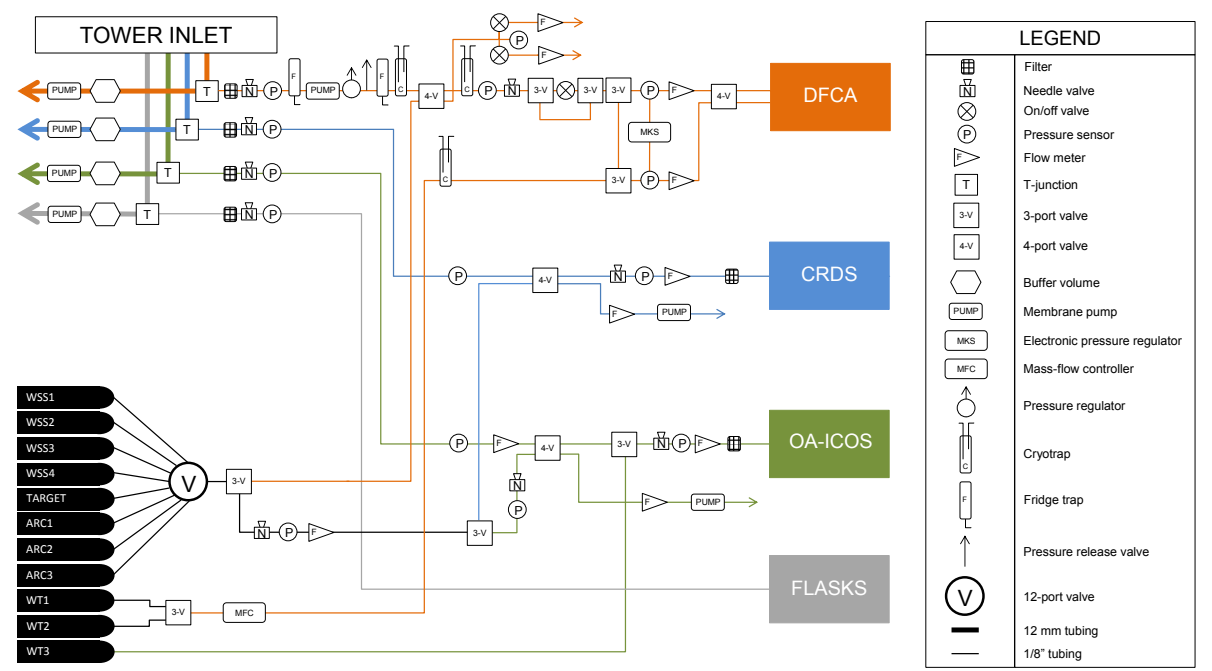

Figure 2. Diagram of the measurement system.

Table 1. Part list of gas handling equipment.

\begin{tabular}{lll}
\hline Item & Manufacturer/brand & Part number \\
\hline Membrane pump & KNF Neuberger GmbH (Germany) & N828KNE \\
Membrane pump (CRDS external) & Vacuubrand GmbH (Germany) & MD1 \\
Membrane pump (flask sampler) & KNF Neuberger GmbH (Germany) & PM226199-814 \\
Microturbine flow meter & Aalborg Instruments and Controls, Inc. (USA) & P11A2-Ba0A \\
Pressure sensor & Sensortechnics GmbH (Germany) & CTE7N01GMO \\
Electronic pressure regulator & MKS Instruments, Inc. (USA) & 223BD-00010AAB \\
Mass flow controller & MKS Instruments, Inc. (USA) & 1179A12CS1AV \\
Twelve-port valve & Valco Instruments Company, Inc. (USA) & EMT2SD12MWE \\
Three-way valve & Numatics, Inc. (USA) & HSN2C6HOOV \\
Four-way valve & Bürkert Fluid Control Systems (Germany) & 0330 \\
Pressure regulators (working tanks) & Scott Specialty Gases, Inc. (USA) & 085C4115 \\
Pressure regulators (reference tanks) & TESCOM (USA) & 64-3440KA412 \\
Peristaltic pump & Masterflex (USA) & 7542-01 \\
Cryo-cooler & FTS Systems (Germany) & VT490D \\
\hline
\end{tabular}

a higher frequency than this are averaged by the software. In addition to the control and data acquisition computer running the LabVIEW software, a second computer is used for off-site data transfer and remote access to the laboratory network.

As both the CRDS and OA-ICOS instruments are upstream of their pumps, these sample lines are underpressurized (100-200 mbar under ambient), and the instruments actively regulate the pressure inside the measurement cavity. The CRDS has been fitted with an external diaphragm pump for better ease of maintenance. Since the DFCA does not have its own pump, air is forced through the analyzer via a small membrane pump located upstream of the fridge traps and cryotraps (Fig. 2); consequently in this region the sample lines are over-pressurized. The residence time of sample air in the entire system was determined to be between 15 and $200 \mathrm{~s}$, depending on which analyzer air was routed to.

\subsection{Carbon dioxide and methane measurements}

The Picarro ESP-1000 (Serial No. CFADS-06) instrument is an early-model CRDS. This optical technique is a type of laser absorption spectroscopy, whereby a continuous wave laser emits a pulse of light into an optical cavity. The laser is tuned to several specific wavelengths where the measurand has strong absorption and to regions without absorption in order to determine the ring-down time with and without absorption by the measurand. The difference in decay time of the light intensity (as measured by a photo-detector) between the two modes is the signal of the analyzer, which is converted to a mole fraction (Crosson, 2008). Since the CRDS software calculates the mole fractions of $\mathrm{CO}_{2}, \mathrm{CH}_{4}$, and $\mathrm{H}_{2} \mathrm{O}$, this output can be used directly, after the application of an instrument-specific water correction and a calibration (see Sects. 2.8 and 2.9, respectively). 
As the CRDS is tuned to specific absorption features, it measures only the main isotopologues of each species, namely ${ }^{12} \mathrm{C}^{16} \mathrm{O}_{2},{ }^{12} \mathrm{C}^{1} \mathrm{H}_{4}$, and ${ }^{1} \mathrm{H}_{2}^{16} \mathrm{O}$ (Crosson, 2008). Therefore, the isotopic composition of calibration standards and other reference gases must be close to that of the sample to avoid artifacts (Chen et al., 2010). Likewise, standard gases should have the same buffer matrix as the sample, meaning that synthetic air standards should not be used (Nara et al., 2012). As the shapes of these spectral lines are quite sensitive to temperature and pressure, the levels of both must be carefully maintained by the instrument. The cavity is held at a constant pressure of $186.7 \pm 0.1$ mbar and a constant temperature of $45 \pm 0.01^{\circ} \mathrm{C}$.

\subsection{Nitrous oxide and carbon monoxide measurements}

The Los Gatos $\mathrm{N}_{2} \mathrm{O} / \mathrm{CO}-23 \mathrm{~d}$ Analyzer employs cavity enhanced absorption off-axis integrated cavity output spectroscopy (OA-ICOS) (Paul et al., 2001; Peltola et al., 2012). In this technique, light from a laser is emitted into a cavity and the temporally integrated intensity of the transmission of the light out of the cavity is the raw measurement signal (Baer et al., 2002). Like the CRDS, the OA-ICOS software calculates the mole fractions of $\mathrm{N}_{2} \mathrm{O}, \mathrm{CO}$, and $\mathrm{H}_{2} \mathrm{O}$; this output is used directly after the application of an instrumentspecific water correction, calibrations, and a drift correction (see Sects. 2.8, 2.9, and 2.10, respectively).

As the instrument is fairly new, few published studies on the analyzer are available, particularly those that evaluate both $\mathrm{N}_{2} \mathrm{O}$ and $\mathrm{CO}$. Initial assessments indicate that the instrument has the potential for use in making atmospheric measurements, eddy covariance methods, and aqueous dissolved gas concentrations measured in equilibrated headspace, provided the drift of the analyzer is accounted for and care is taken with respect to gas handling, since the mole fraction ranges are usually small (Zellweger et al., 2012; Blomquist et al., 2012; Arévalo-Martínez et al., 2013).

\subsection{Atmospheric oxygen measurements}

The DFCA measures the $\mathrm{O}_{2}$ mole fraction directly in dry air through an electrochemical method (Thompson et al., 2007, 2009; Stephens et al., 2007). There are two sensors in the device, each containing an anode, cathode, and weak acid electrolyte. Atmospheric oxygen is reduced on the cathode, generating a current which is the analytical signal. Differences in pressure on the sensor will necessarily result in a higher signal; therefore pressures and flows must be kept completely uniform. In practice this is quite challenging, so to minimize artifacts measurements of reference gases or sample air are always made differentially against a dedicated reference cylinder that flows continuously while the instrument is operational. Since it is not necessary to know the exact $\delta\left(\mathrm{O}_{2} / \mathrm{N}_{2}\right)$ content of this reference gas, it is not measured; such a cylinder is called a "working tank". A four-port two-way valve switches between these two streams every $1.5 \mathrm{~min}$ to avoid artifacts from the drift of either fuel cell, and computation of the final $\delta\left(\mathrm{O}_{2} / \mathrm{N}_{2}\right)$ is thus made relative to both the difference between the two fuel cells and between the sample air and reference gas within one fuel cell:

$\Delta_{\text {raw }}=\left[\left(C_{\mathrm{WT}}^{1}-C_{X}^{1}\right)-\left(C_{X}^{2}-C_{\mathrm{WT}}^{2}\right)\right]$,

$\delta\left(\mathrm{O}_{2} / \mathrm{N}_{2}\right)=\frac{\Delta_{\mathrm{cal}}+\left[\left(\mathrm{CO}_{2}\right)_{\mathrm{M}}-\left(\mathrm{CO}_{2}\right)_{\mathrm{ref}}\right] \cdot S_{\mathrm{O}_{2}}}{\left(1-S_{\mathrm{O}_{2}}\right) \cdot S_{\mathrm{O}_{2}}}$.

Here $C$ is the raw measurement from the DFCA fuel cells in percent. The subscript refers to a discreet measurement of the working tank $\left(C_{\mathrm{WT}}\right)$ or the gas stream one wishes to quantify $\left(C_{X}\right)$, be it a reference gas or sample air. The numbered superscripts refer to fuel cell/channel 1 or 2 . Each value of $C$ represents the average of $1 \mathrm{~s}$ measurements for the duration of the period between switches. The first $30 \mathrm{~s}$ of this period are discarded, as the fuel cell has to stabilize after a valve switch. Solving Eq. (1) gives the uncalibrated differential signal, $\Delta_{\text {raw }}$. After a calibration is applied (see Eq. 7), $\Delta_{\text {cal }}$ is used to calculate the final $\mathrm{O}_{2} / \mathrm{N}_{2}$ in per meg, as per Eq. (2), after Stephens et al. (2003) and Kozlova et al. (2008). $\left(\mathrm{CO}_{2}\right)_{\mathrm{M}}$ is the final dry mole fraction in parts per million as measured by the CRDS, and $\left(\mathrm{CO}_{2}\right)_{\text {ref }}$ is an arbitrary reference value of the Scripps scale, $363.29 \mathrm{ppm}$. $S_{\mathrm{O}_{2}}$ is the average mole fraction of $\mathrm{O}_{2}$ in standard dry air, 0.209392 (Tohjima et al., 2005).

The working tank gas flow is controlled precisely by a mass-flow controller (MKS Instruments, Andover, MA, USA). A pressure transducer (also MKS) measures the pressure difference between the two gas streams and a proportional valve equalizes the pressures so that they do not vary by more than \pm 0.2 mbar.

We also present some atmospheric potential oxygen (APO) data in this paper as a further evaluation of data quality since they are a synthesis of both atmospheric oxygen and carbon dioxide measurements. APO is a data-derived tracer for the portion of atmospheric oxygen that is influenced by marine processes and is defined here via the more common, simplified formulation (Stephens et al., 1998; Gruber et al., 2001; Battle et al., 2006; Keeling and Manning, 2014) as

$\mathrm{APO}=\delta\left(\mathrm{O}_{2} / \mathrm{N}_{2}\right)+\frac{1.1}{X_{\mathrm{O}_{2}}}\left(\mathrm{CO}_{2}-350\right)$.

Here $X_{\mathrm{O}_{2}}$ is the mole fraction of $\mathrm{O}_{2}$ in standard air, and 350 is the dry mole fraction of $\mathrm{CO}_{2}$ in ppm in the same. $\mathrm{CO}_{2}$ is the dry mole fraction in ppm, which must be measured simultaneously with $\delta\left(\mathrm{O}_{2} / \mathrm{N}_{2}\right)$. Both APO and $\delta\left(\mathrm{O}_{2} / \mathrm{N}_{2}\right)$ are in per meg. The factor 1.1 is the approximate global stoichiometric ratio of $\mathrm{O}_{2}$ to $\mathrm{CO}_{2}$ surface-atmosphere exchange of the change in both species due to the terrestrial biosphere (Severinghaus, 1995). 


\subsection{Flask sampling}

In order to provide an independent corroboration of the in situ data, flask samples were taken on a (nominally) weekly basis, with variations in timing and small gaps due to personnel availability. Since sampling is done manually, the time of day is always between sunrise and sunset, but typically in the afternoon. This preferentially samples the coastal wind sector, since a strong sea breeze is common (but not assured) during the afternoon hours at NDAO. Meteorological conditions are not taken into account during sampling, however, as there are no strong local sources of contamination, provided the generator is not running. All species that are measured continuously at the station are also measured in flasks; additionally the flasks are also analyzed for $\delta^{13} \mathrm{C}-\mathrm{CO}_{2}, \delta{ }^{13} \mathrm{C}-$ $\mathrm{CH}_{4}, \delta^{18} \mathrm{O}-\mathrm{CO}_{2}, \delta \mathrm{D}-\mathrm{CH}_{4}, \mathrm{H}_{2}, \mathrm{Ar} / \mathrm{N}_{2}$, and $\mathrm{SF}_{6}$.

The flasks used by the Max Planck Institute for Biogeochemistry (MPI-BGC) are borosilicate glass and $1 \mathrm{~L}$ in volume, with two valves equipped with Kel- $F^{\circledR}$ (polychlorotrifluoroethylene, PCTFE) seals. PCTFE has been shown to have a low permeability to most gases compared to other common sealing materials, as long storage times can change the composition of sample air in flasks (Sturm et al., 2004). Flasks are shielded from light exposure with a black sheath. Before sampling the flasks are pre-conditioned by evacuation at $60^{\circ} \mathrm{C}$ for $72 \mathrm{~h}$ and then filled with dry air at a pressure of 1.6 bars.

Samples are taken in triplicate and connected in series upstream of a pump. A dedicated line (identical to the continuous sample lines) is used exclusively for the flasks, although the portion that is downstream of the main pump is not flushed or purged when not in use. The pump body and valve plates are aluminum, and the structured diaphragms are made of PCTFE. When in use the flow rate $\left(3.2 \mathrm{~L} \mathrm{~min}^{-1}\right)$ is higher than the in situ analyzer flow rates $\left(100-200 \mathrm{~mL} \mathrm{~min}^{-1}\right)$. Air is dried with a cryotrap identical to the one used for the oxygen sampling line. During sampling, the line is flushed for $5 \mathrm{~min}$ before any air is directed to the flasks, then a bypass is opened and the flasks are flushed for an additional $15 \mathrm{~min}$ before they are sealed again. After closure, the pressure of the flask is about 1.6 bars.

Due to the lengthy shipping route and remote location of the station, storage time of flasks can be lengthy - the mean number of storage days is 100 , the maximum thus far is 226 - and for reactive species like CO this can result in storagerelated artifacts and/or permeation.

Laboratory demands and a large volume of samples from this and other stations in the MPI-BGC network mean that not all flasks are analyzed for all species, and in the case of methane isotopic composition, only two out of three flasks are analyzed. $\delta\left(\mathrm{O}_{2} / \mathrm{N}_{2}\right)$ is measured with mass spectrometry, $\mathrm{CH}_{4}, \mathrm{CO}_{2}$, and $\mathrm{CO}$ with GC-FID, and $\mathrm{N}_{2} \mathrm{O}$ with GC-ECD. Isotopic ratios are determined with isotope ratio mass spectrometry.

\subsection{Meteorological measurements}

A small meteorological sensor array is located at the inlet height on the mast. Wind direction and wind speed are measured with a Thies Clima 2-D sonic anemometer (model 4.3810.30.310), temperature and relative humidity with a combined Galltec-Mela instrument (model C 2.4), barometric pressure with a Young pressure sensor (model 61202V), and solar irradiance with a Kipp and Zonen ISO 9060 first class pyranometer (model CMP11). Data are passed to the LabVIEW system via a controller area network (CAN bus).

\subsection{Sensor stability}

In order to characterize the stability of the main instruments, a stream of dry air with a constant composition was supplied to each device for a $24 \mathrm{~h}$ period during the final stages of the laboratory installation on site. From this the Allan variance was computed. The Allan variance, a method for computing the frequency stability of clocks, can also be used to analyze the noise of a sensor (Siraya, 2001; Land et al., 2007). Allan variance is given as

$\sigma_{y}^{2}(\tau)=\frac{\sum_{i=1}^{N-2 n+1}\left(T_{i+2 n}-2 T_{i+n}+T_{i}\right)^{2}}{2 \tau^{2} \cdot(N-2 n+1)}$,

where $\tau$ is the sampling interval, $N$ is the number of measurements of some quantity $T_{i}$, and $n$ is the number of adjacent values of $T_{i}$ in $\tau$ (Land et al., 2007). Akin to the standard deviation, the Allan deviation is the square root of the variance,

$\sigma_{y}(\tau)=\sqrt{\sigma_{y}^{2}(\tau)}$.

The advantage of the Allan deviation is that it is determined in the same units as the measurand is reported. In some cases, the minimum value of the deviation is the ideal averaging interval for the sensor, being the integration time for which sensor noise is the lowest. In practice, however, the integration time that yields the lowest deviation may be too large to be practical.

\subsection{Drying and water correction}

The absolute abundance of water vapor varies widely throughout the atmosphere; even under well-mixed conditions in the troposphere, the mixing ratio of $\mathrm{H}_{2} \mathrm{O}$ can span several percent. This dilutes the mixing ratio of trace gases and can obscure their "true" variability if mole fractions are not determined against moles of dry air.

As both the CRDS and OA-ICOS instruments measure water vapor, they afford the opportunity to dispense with sample drying and apply a water correction instead. There are drawbacks to any water correction or drying method. Sample drying introduces a physical alteration of the sample matrix and increases the total number of seals and connections of 
the gas handling system which must be rendered gas tight. Drying also generally requires additional consumables. Finally, depending on the method used there is also contingent maintenance required to remove the collected water, which can be problematic at remote sites.

Water corrections, however, require continuous, extremely precise, stable measurements of water vapor, which is analytically challenging. It is also a newer approach and as such represents a major break in methodological continuity, a concern for long-term time series. Switching between humid (sample) and dry (reference) air streams is also not ideal. Nevertheless, the method has been shown to be robust for measurements of $\mathrm{CO}, \mathrm{CO}_{2}$, and $\mathrm{CH}_{4}$ with the type of instrumentation at NDAO (Nara et al., 2012; Chen et al., 2010; Winderlich et al., 2010; Rella et al., 2013; Zellweger et al., 2012).

It was decided to forgo sample drying for the CRDS and OA-ICOS instruments at NDAO for several reasons: first, the station is in a desert environment, where water vapor mole fractions are typically less than $2 \%$ and water corrections perform best; second, since the site is remote and there are no formally trained technicians available, simple maintenance procedures are greatly preferred; third, the precise, continuous measurements of $\mathrm{H}_{2} \mathrm{O}$ made by the CRDS can be corrected to yield accurate observations of water vapor, data which otherwise would be unavailable (Winderlich et al., 2010); and fourth, this obviates the need for drying greatly simplifies the plumbing system for these two instruments, both of which operate under ambient pressure, and reduces the potential for leaks inside the laboratory.

A version of the "water droplet" method was used to humidify the air stream of a target gas cylinder, using a slight variant of one of the methods in Rella et al. (2013) (Method 2, "Empa variation"). The apparatus allows the operator to easily switch between dry and humidified gas streams with the aid of the manual valves. The gas stream passes over the surface of a water droplet $(<200 \mu \mathrm{L})$ placed in a small well. After the water droplet is completely evaporated and the residual humidity in the tubing is fully removed, the entire shape of the correction function is delimited. The "tuning" parameters used to achieve a sufficient initial water vapor concentration are the height of the tubing over the droplet, the absolute pressure in the trap, and the temperature of the lab (J. Winderlich, personal communication, 2013).

Due to broadening effects on the spectral lines, both the CRDS and the OA-ICOS must be water corrected for each species, $X$, with a second-order function, in the form of (Chen et al., 2010; Winderlich et al., 2010):

$\frac{X_{\text {wet }}}{X_{\text {dry }}}=1+a \cdot \mathrm{H}_{2} \mathrm{O}_{\text {rep }}+b \cdot \mathrm{H}_{2} \mathrm{O}_{\text {rep }}^{2}$.

$\mathrm{H}_{2} \mathrm{O}_{\text {rep }}$ is the mole fraction of water vapor measured by the instrument in question without correction, usually in percent, and $a$ and $b$ are empirically determined factors determined
Table 2. Measurement compatibility with cape point observatory and MPI-BGC (flask vs. in situ), with reference to WMO/GAW goals (WMO/GAW, 2013).

\begin{tabular}{lrrrr}
\hline Measurand & $\begin{array}{r}\text { Compatibility } \\
\text { Goal }\end{array}$ & MPI-BGC & $\begin{array}{r}\text { Cape } \\
\text { Point }\end{array}$ & Unit \\
\hline $\mathrm{CO}_{2}$ & 0.05 & 0.14 & 0.1 & ppm \\
$\mathrm{CH}_{4}$ & 2 & 1.6 & 1.2 & $\mathrm{ppb}$ \\
$\mathrm{N}_{2} \mathrm{O}$ & 0.1 & 0.33 & 1.3 & $\mathrm{ppb}$ \\
$\mathrm{CO}$ & 2 & 4.5 & 0.2 & $\mathrm{ppb}$ \\
$\delta\left(\mathrm{O}_{2} / \mathrm{N}_{2}\right)$ & 2 & 9.4 & - & per meg \\
\hline
\end{tabular}

by the experiment described above. The results of the water corrections are discussed in Sect. 3.5.

\subsection{Calibrations and system performance evaluation}

The recommendations for measurement compatibility between and within different laboratories and measurement sites made by the Global Atmosphere Watch Programme of the World Meteorological Organization (WMO/GAW) are given in Table 2 . We used these compatibility goals as guidelines for evaluating target measurements and instrument error.

All reference gases are stored horizontally in an insulated box to minimize stratification and temperature fluctuations. Reference gases are calibrated against primary standards at the Max Planck Institute for Biogeochemistry (MPI-BGC) GASLAB for $\mathrm{CO}_{2}, \mathrm{~N}_{2} \mathrm{O}, \mathrm{CO}$, and $\mathrm{CH}_{4}$. The $\mathrm{O}_{2} / \mathrm{N}_{2}$ ratio of reference cylinders is measured at MPI-BGC by mass spectrometry. All measurements were tied to primary standards on the following scales: WMO X2007 for $\mathrm{CO}_{2}$, NOAA 2004 for $\mathrm{CH}_{4}$, NOAA 2006a for $\mathrm{N}_{2} \mathrm{O}$, WMO X2004 for $\mathrm{CO}$, and the Scripps Institute for Oceanography scale for $\delta\left(\mathrm{O}_{2} / \mathrm{N}_{2}\right)$. All reference gases are comprised of dry ambient air and stored in $50 \mathrm{~L}$ aluminum cylinders. The initial pressure of each cylinder is 200 bar. Calibration of the instruments is done through four working secondary standards and instrument performance is periodically checked with "target" cylinders (i.e., tanks of known mole fraction which are regularly remeasured). Atmospheric abundances of $\mathrm{CO}_{2}, \mathrm{CH}_{4}$, $\mathrm{N}_{2} \mathrm{O}$, and $\mathrm{CO}$ all are reported as dry air mole fractions, e.g., $1 \mu \mathrm{mol} \mathrm{mol}{ }^{-1}=1 \mathrm{ppm}$.

Instrument calibrations are performed automatically by the LabVIEW program. The set points of these tanks were selected to bracket the natural variability which was expected for this site. Mole fraction ranges were $370-410 \mathrm{ppm}$ for $\mathrm{CO}_{2}, 1600-1920$ ppb for $\mathrm{CH}_{4}, 300-340$ ppb for $\mathrm{N}_{2} \mathrm{O}, 40$ $250 \mathrm{ppb}$ for $\mathrm{CO}$, and between -300 and -700 per meg for $\delta\left(\mathrm{O}_{2} / \mathrm{N}_{2}\right)$. The interval between calibrations was $123 \mathrm{~h}$ for the CRDS and OA-ICOS and $71 \mathrm{~h}$ for the DFCA. Target measurements were made every $49 \mathrm{~h}$ for the CRDS and every $35 \mathrm{~h}$ for the OA-ICOS and DFCA. Various schemes were implemented, but the ones used represent the best compro- 
mise between the need to save reference gases and the drift of the sensors. As preparation, shipment, customs clearance, and local delivery of a pallet of cylinders to NDAO from MPI-BGC in Germany usually takes about 1 year, we implemented the most conservative (in terms of gas usage) calibration frequency possible without unduly compromising measurement accuracy.

Reference gases (working secondary standards or targets) were measured for a total of 12 min after a 2 min high-flowrate $\left(250 \mathrm{~mL} \mathrm{~min}^{-1}\right)$ purge of the sample line. During purges the reference gas flow is not directed to the instrument but vented at the junction closest to the instrument. A stable signal is generally reached after 6 min of measurements for all measurands. As non-linearity was not observed for any instrument in the set point ranges of tanks used at NDAO, the instrument response functions for all species were taken as a linear fit of the average of the last 5 min of working secondary standards measurements and the mole fraction determined by the MPI-BGC facilities:

$y=m x+b$,

where $x$ is the "true" value of the measurand, supplied by the analytical facilities at MPI-BGC, and $y$ is the dry air mole fraction or $\mathrm{O}_{2}$ to $\mathrm{N}_{2}$ ratio measured by the instrument during a specific calibration. The slope $(m)$ and intercept $(b)$ are linearly interpolated between calibrations.

A dedicated reference cylinder was used as a target tank to assess long-term repeatability and instrument precision. Target measurements are an imperfect descriptor of system performance, or at least not a complete guarantor of data quality, since such measurements would not reveal a leak in air sampling lines upstream of the common tee. In the case of our measurement system, the pressure of sample line of the CRDS and OA-ICOS while measuring target gas is slightly over ambient and dry, meaning it is measured under different conditions from sample air. For some species, like $\mathrm{CO}_{2}$, there can be small adsorption-related artifacts during gas storage or gas handling which might appear to be due to poor instrument performance but would not be shared by the in situ time series. Nevertheless, regular target measurements can reveal long-term problems or biases and can give an estimate of measurement uncertainty and repeatability.

Following in part the recommendations of Andrews et al. (2014), we report the measurement uncertainty as the targetderived measurement uncertainty (see Eqs. 9a-d in Andrews et al., 2014). This quantity, $\boldsymbol{u}_{\mathrm{TAR}}$, was calculated as the 67 th percentile of the absolute value of the difference between the laboratory assigned value or "set point" and the individual mean target determination in a moving window of 1 week.

\subsection{Drift correction of the OA-ICOS analyzer}

During laboratory tests before the deployment of the OAICOS instrument, it became apparent that it is susceptible to temperature and pressure-related drift. Our Los Gatos ana- lyzer does not have the improved temperature control that later models do (the "enhanced performance" feature). We opted to attempt to correct this drift empirically by measuring a working tank at $2 \mathrm{~h}$ intervals, a determination arrived at through consideration of the rate and magnitude of the sensor drift, the loss of in situ data, and the usage rate of the working tank.

Data are corrected for drift after the water correction but before applying the calibration. Each working tank measurement lasts $8 \mathrm{~min}$, without a line purge, and only the last $2 \mathrm{~min}$ are used. A spline is fit through the average of all working tank measurements made on the same tank, and the difference of these interpolated measurements from the mean of the tank is then applied to each time step as a correction factor.

\section{Results and discussion}

\subsection{General performance of the measurement system}

High temperatures are a major challenge of working at this site, and maintaining a constant temperature in the laboratory and for the devices is crucial. The CRDS and DFCA are both housed in an insulated rack, which reduces the range of temperatures the devices are exposed to compared to the variation in the laboratory itself. The standard deviation of the air temperature laboratory was $1.5^{\circ} \mathrm{C}$ over the operational lifetime of the station and $0.77^{\circ} \mathrm{C}$ for the instrument rack; for comparison the value for the in situ air temperature was $6.8^{\circ} \mathrm{C}$. The CRDS cavity temperature was stable within $0.02^{\circ} \mathrm{C}$. The OA-ICOS fared less well since it was too large to fit inside the rack $\left(1 \sigma=0.90^{\circ} \mathrm{C}\right)$. An insulated box was built for it instead, with active ventilation control. The insulated box performed better than no protection at all but is still not as efficient as the rack, which is reflected in the OA-ICOS instrument temperature; it should be noted, however, that the CRDS has superior temperature control for its measurement cell. For the DFCA, which also has active temperature control, the standard deviation was $0.05^{\circ} \mathrm{C}$.

There is one large gap in the record during July 2013 when the hard drive of the control and data acquisition computer failed. This was a solid-state drive (SSD), and there is some evidence to suggest that these drives are more prone to failure than traditional hard drives $(\mathrm{Ku}, 2011)$. Given that the SSD of the communication computer also failed in January 2014, we have forsworn the use of SSDs at NDAO in favor of traditional hard drives.

The second large gap in the records of $\delta\left(\mathrm{O}_{2} / \mathrm{N}_{2}\right), \mathrm{CO}_{2}$, $\mathrm{CH}_{4}$, and $\mathrm{H}_{2} \mathrm{O}$ is due to a dust storm during a berg-wind event which clogged the CRDS sample line shortly after the communication computer failed and remote connection with the site was no longer possible. The DFCA sample line was not as affected but $\delta\left(\mathrm{O}_{2} / \mathrm{N}_{2}\right)$ requires in situ $\mathrm{CO}_{2}$ data. Due to the large amount of fine dust at the site, filters have to 

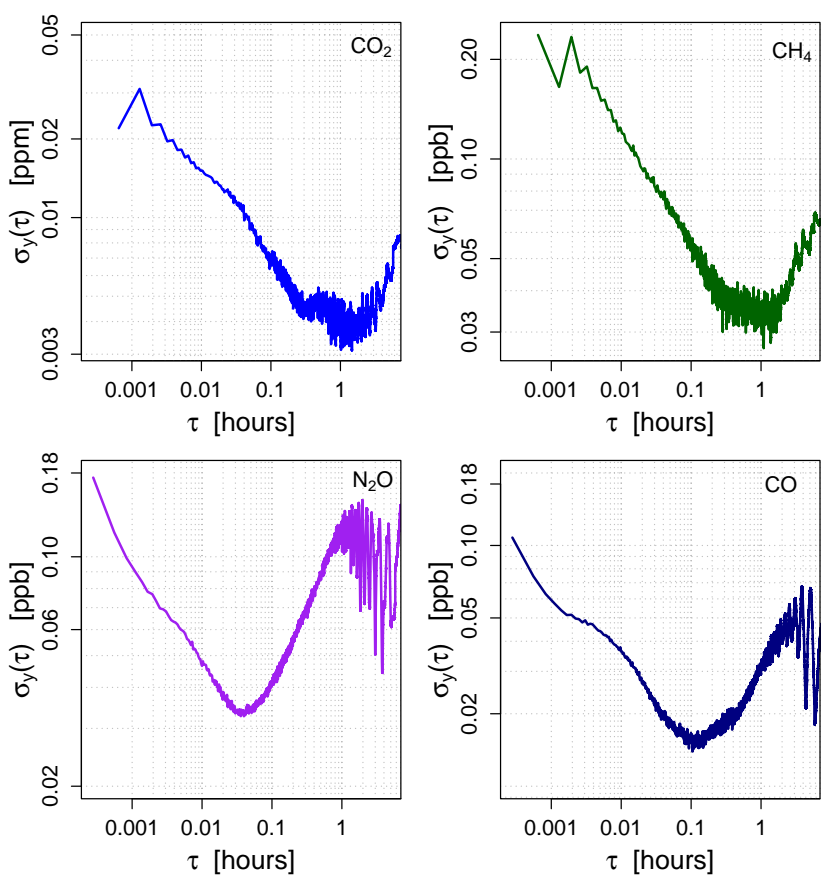

Figure 3. Log-log plots of the Allan deviations of the output of the CRDS and OA-ICOS instruments as they received gas flow from a working tank for $24 \mathrm{~h}$.

be exchanged frequently and flow rates generally slowly decline as they are clogged; sudden events, however, can cause a rapid decline in flow and pressure in the sample lines and necessitate shutdown until the filters can be replaced.

The data stream also has smaller gaps, due to calibrations, target measurements, LabVIEW software issues, or maintenance. Software and computer issues, rather than instrument failure, is probably the more common cause of data gaps related to technical problems; the exception to this was from March to July 2013, when the station was plagued by frequent (sometimes daily) power outages. Nevertheless, absolute data coverage since October 2012 is approximately $75 \%$ or higher for most measurands.

The time series for $\mathrm{N}_{2} \mathrm{O}$ and $\mathrm{CO}$ start 8 months after the beginning of the station operation due to a leak in the tower line developed a few weeks after installation and contaminated the line with air conditioner exhaust. Long ( $>24 \mathrm{~h}$ ) leak tests were performed during site installation and again after the OA-ICOS leak was discovered and fixed. The leak test was conducted by capping the top of the sample line on the mast and capping the tubing just upstream of the device. The line was then evacuated with a small hand pump to the typical operating pressure of the sample line. After accounting for temperature fluctuations, leak rates determined after this time were lower than $3.0 \times 10^{-4} \mathrm{mbarL}^{-1} \mathrm{~s}^{-1}$, which we estimate, under worst-case scenarios, would result in artifacts smaller than $0.014 \mathrm{ppm}$ for $\mathrm{CO}_{2}, 0.0017 \mathrm{ppb}$ for $\mathrm{CH}_{4}$, $7.6 \times 10^{-5} \mathrm{ppb}$ for $\mathrm{N}_{2} \mathrm{O}$, and $0.0052 \mathrm{ppb}$ for CO. Fractiona-
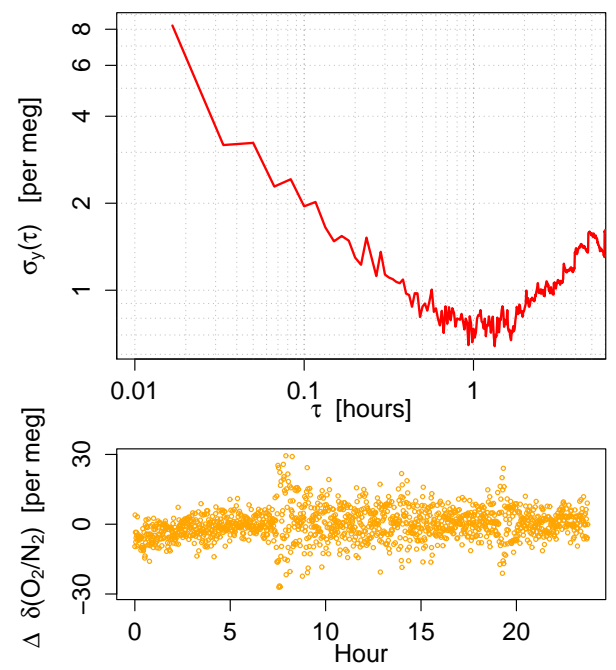

Figure 4. $\log -\log$ plot of the Allan deviation of the DFCA for the $24 \mathrm{~h}$ of working tank flow (top panel) and anomaly of $\delta\left(\mathrm{O}_{2} / \mathrm{N}_{2}\right)$, calculated as the instantaneous data minus the mean of the whole test (bottom panel).

tion tests were performed for the DFCA sample line, which resulted in no detectable fractionation.

\subsection{Stability of the CRDS}

The Allan deviation of both $\mathrm{CO}_{2}$ and $\mathrm{CH}_{4}$ exhibit minima around the 1 to $1.5 \mathrm{~h}$ window (Fig. 3), after which the drift of the sensor begins to dominate. In the case of $\mathrm{CO}_{2}$, this drift was clearly (inversely) dependent on the air temperature surrounding the working tank, as measured by a temperature sensor inside the insulated box housing all cylinders. Correlations were not seen with rack temperature, regulator temperature (housed outside of the insulated box for cylinders), or room temperature. While it is not atypical for Picarro CRDS analyzers to drift with temperature to this degree (Crosson, 2008), the evidence points to an artifact related to the tank. The effect is about $-0.06 \mathrm{ppm}^{\circ} \mathrm{C}^{-1}$ over a $24 \mathrm{~h}$ period. A weaker relationship with opposite sign was seen for methane. Repetitions of this test during maintenance visits have shown similar results.

Using the raw (i.e., uncalibrated) target measurements as an assessment of the long-term drift of the instrument, we note that long-term drift was not linear over the entire measurement period but wandering due to a slight seasonality in the temperature of the laboratory. The absolute range of raw target measurements on one tank was $0.4 \mathrm{ppm}$ for $\mathrm{CO}_{2}$ and $2.3 \mathrm{ppb}$ for $\mathrm{CH}_{4}$.

\subsection{Stability of the OA-ICOS}

While the OA-ICOS is very precise over short intervals, it is much more prone to drift than the CRDS. The optimal averaging interval for this instrument is around $100 \mathrm{~s}$ for both 

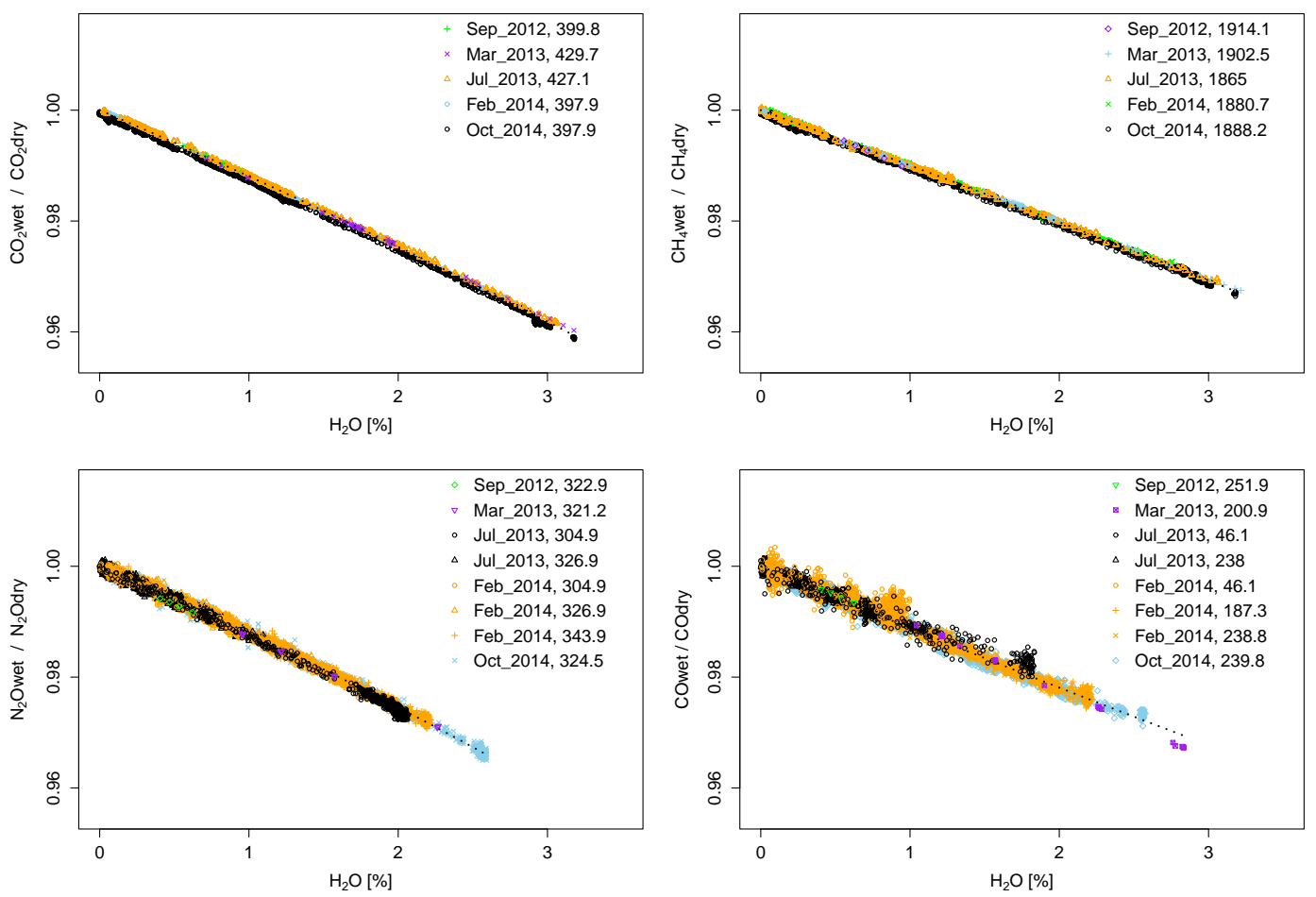

Figure 5. Water correction functions from different tests for all measurands. Colors represent different dates, and shapes represent specific mole fractions of the cylinder used for the test, all in ppb except for $\mathrm{CO}_{2}$, which is in $\mathrm{ppm}$.

species, after which drift begins to dominate the sensor error. The OA-ICOS is prone both to sudden spikes and rapid linear drift when the instrument heats or cools the cavity to maintain a constant temperature. Raw target measurements over 2 years showed a maximal spread of $2.9 \mathrm{ppb}$ for $\mathrm{N}_{2} \mathrm{O}$ and $0.8 \mathrm{ppb}$ for $\mathrm{CO}$, although the long-term drift was not linear but governed by laboratory temperature.

\subsection{Stability of the DFCA}

Due to the differential nature of the DFCA, characterizing the noise of the individual sensors would serve little purpose, since the operator expects that the absolute signal of both fuel cells will drift. The simplest and most meaningful test of sensor stability in the case of this instrument was to provide both fuel cells with flow from a working tank and calculate the Allan deviation of the differential signal (Fig. 4, top panel), regardless of the low frequency of measurements.

From the time series of the DFCA output (Fig. 4, bottom panel), it seems that the analyzer took roughly $5 \mathrm{~h}$ to stabilize during the stability test. This apparent start-up drift is fairly small and could represent a gradual flushing of the regulator. Despite some small, sudden spikes, the DFCA shows the least dependence of the main instruments on the temperature and pressure of its environment, not surprising since the nature of the dual differential measurement should cancel out temperature effects. WMO/GAW compatibility goals for
$\delta\left(\mathrm{O}_{2} / \mathrm{N}_{2}\right)$ can be reached with an averaging interval greater than $7 \mathrm{~min}$.

While the fuel cells have been monitored for degradation, no detectable loss in sensitivity has been noticed over the 2 years of operation.

\subsection{Water correction of the CRDS}

The aggregated results of several water correction tests can be seen in Fig. 5. The final fit parameters applied to the time series were determined as a quadratic fit to all tests, and were consistent between tests and across a range of mole fractions. The coefficients show small but significant differences from other values reported in the literature for similar instruments (Table 3), highlighting the importance of performing instrument-specific water correction tests with this class of CRDS. For instance, using the values from Rella et al. (2013) to correct a NDAO $\mathrm{CO}_{2}$ wet value of $390 \mathrm{ppm}$ at $1.5 \%$ water vapor content would result in a difference of $0.23 \mathrm{ppm}$. It should be noted that the reference values cited from the literature were obtained using different models of the same CRDS instrument. If one wishes to use the CRDS to measure water vapor, the values produced by the instrument (here referred to as $\mathrm{H}_{2} \mathrm{O}_{\text {rep }}$ ) must be corrected to acquire values for $\mathrm{H}_{2} \mathrm{O}_{\text {act }}$, the true absolute mole fraction of water vapor. $\mathrm{H}_{2} \mathrm{O}_{\text {act }}$ can be determined as (Winderlich et al., 2010)

$$
\mathrm{H}_{2} \mathrm{O}_{\text {act }}=0.0292+0.7718 \cdot \mathrm{H}_{2} \mathrm{O}_{\text {rep }}+0.0197 \cdot \mathrm{H}_{2} \mathrm{O}_{\text {rep }}^{2} \text {. }
$$


Table 3. Comparison of water correction function fit parameters (Eq. 6), with water vapor in percent.

\begin{tabular}{llrr|rr}
\hline Reference & Model & \multicolumn{2}{c}{$\mathrm{CO}_{2}$} & \multicolumn{2}{c}{$\mathrm{CH}_{4}$} \\
\cline { 3 - 5 } & & $a \times 10^{-2}$ & $b \times 10^{-4}$ & $a \times 10^{-2}$ & $b \times 10^{-4}$ \\
\hline This work & ESP-1000 & -1.15 & -3.94 & -0.98 & -1.36 \\
Winderlich et al. (2010) & EnviroSense 3000i & -1.21 & -2.03 & -1.01 & -1.45 \\
Chen et al. (2010) & G1301 & -1.20 & -2.67 & -0.98 & -2.39 \\
Rella et al. (2013) & Various & -1.21 & -2.48 & -1.02 & -1.40 \\
\hline & & $\mathrm{N}_{2} \mathrm{O}$ & \multicolumn{2}{c}{$\mathrm{CO}$} \\
\cline { 3 - 6 } & & $a \times 10^{-2}$ & $b \times 10^{-4}$ & $a \times 10^{-2}$ & $b \times 10^{-4}$ \\
\hline This work & $\mathrm{N}_{2} \mathrm{O} / \mathrm{CO}-23 \mathrm{~d}$ & -1.14 & -6.46 & -1.09 & 0.14 \\
\hline
\end{tabular}

This relationship is thought to hold between Picarro CRDS instruments, since they are all calibrated on the same scale during manufacture. A major assumption here is that the absolute drift of the water vapor signal is negligible. It should also be noted that the OA-ICOS instrument was not used for determining $\mathrm{H}_{2} \mathrm{O}_{\text {act }}$, since tests showed that it was both less accurate and less sensitive than the CRDS; the water vapor data from the OA-ICOS is used only for correction.

\subsection{Water correction of the OA-ICOS}

Table 3 gives the values of the coefficients for a second-order water correction for both $\mathrm{N}_{2} \mathrm{O}$ and $\mathrm{CO}$. Given the only recent availability of the instrument, and the greater prevalence of drying, there are no coefficients to compare to. Zellweger et al. (2012) performed a thorough comparison of the response of several different analyzers to water vapor, including the OA-ICOS $\mathrm{N}_{2} \mathrm{O} / \mathrm{CO}-23 \mathrm{~d}$, but only considered carbon monoxide.

We also note that the absolute mole fraction of water vapor reported by the OA-ICOS disagrees considerably with that of the Picarro (which in part accounts for the lower water vapor mole fractions displayed in Fig. 5 for the OA-ICOS), the OAICOS values being $2329 \mathrm{ppm}(1 \sigma=342 \mathrm{ppm})$ lower on average. We verified the accuracy of the CRDS water vapor measurements by comparing them to water vapor mole fractions derived from in situ NDAO relative humidity, temperature, and barometric pressure. Effectively, this means that the OAICOS instrument cannot detect values below $\sim 2000 \mathrm{ppm}$, which results in artifacts during reference gas cycles (targets and calibration runs), as the air stream continues to dry after the instrument returns a 0 value for water vapor and the water correction cannot be applied. In fact, much of the scatter in the $\mathrm{N}_{2} \mathrm{O}$ time series is related to periods of higher relative humidity and water vapor mole fraction in the in situ measurements.

Finally it should be mentioned that the OA-ICOS's internal water correction is not sufficient to remove the full influence of water vapor and does not account for the quadratic nature of the response curve to water vapor for both $\mathrm{N}_{2} \mathrm{O}$ and $\mathrm{CO}$. When one compares the dry air mole fraction using the OA-ICOS linear internal water correction to the secondorder water correction function used in this work, the two diverge with increasing water vapor mole fraction. For instance, an error of approximately $1.8 \mathrm{ppb}$ at an ambient water vapor mole fraction of $\mathrm{H}_{2} \mathrm{O}_{\text {rep }}=20000 \mathrm{ppm}$ or $\sim 3.5 \mathrm{ppb}$ at a mole fraction of $30000 \mathrm{ppm}$ would be produced for $\mathrm{N}_{2} \mathrm{O}$ using the linear function relative to the quadratic. For $\mathrm{CO}$ the effect was less pronounced but would result in errors of 0.7 and $1.5 \mathrm{ppb}$, respectively.

\subsection{Calibrations}

Calibrations were subjected to quality control (QC) assessments and discarded when they failed to meet specific QC targets for individual species.

For the CRDS, $4 \%$ of calibrations were excluded based on the following QC criteria: a coefficient of determination greater than 0.999 , a deviation from the mean slope greater than 0.002 (unitless; $\mathrm{ppm} / \mathrm{ppm}$ ) or a deviation from the mean intercept larger than $1 \mathrm{ppm}$. For $\mathrm{CH}_{4}$, the QC flags were $0.999,0.02$, and $10 \mathrm{ppb}$, respectively. This approach ensures that anomalous calibration coefficients were not used in producing the final time series. In most cases the poor calibrations were related to recent power outages or large variations in temperature in the laboratory, and the species causing the flag was $\mathrm{CO}_{2}$. The mean $R^{2}$ was 0.9999987 for $\mathrm{CO}_{2}$ and 0.999995 for $\mathrm{CH}_{4}$.

Due in almost all instances to $\mathrm{N}_{2} \mathrm{O}$ not meeting QC standards, $20 \%$ of the OA-ICOS calibrations were rejected. The QC standards were: greater 0.999 coefficient of determination, slope deviation from the mean not greater than 0.015 , and an intercept within $\pm 5 \mathrm{ppb}$ of the mean of all intercepts. For CO the corresponding values were $0.99996,0.02$, and $1 \mathrm{ppb}$. The mean $R^{2}$ was 0.99997 for $\mathrm{N}_{2} \mathrm{O}$ and 0.999989 for CO.

In the case of atmospheric oxygen, $33 \%$ of calibrations were discarded, most of these during a period of frequent power outages and hence poor temperature control in the instrument rack. The QC criteria were an $R^{2}>0.99$, a slope 


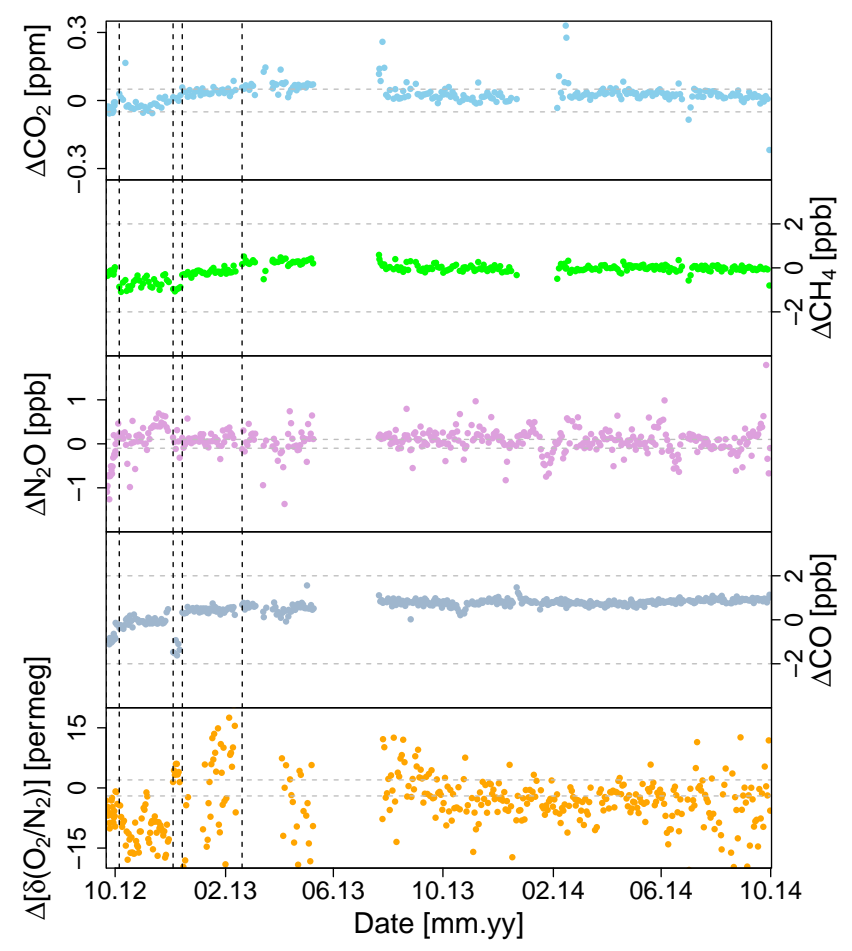

Figure 6. Target measurements for all measurands over the station lifetime, plotted as measured value minus assigned value for each cylinder. The assigned value comes from analysis done at MPIBGC laboratories. The biases of each tank (differences between the MPI-BGC assigned value and the average NDAO determination) are given in Table 4 . The dashed vertical lines indicate a target tank change and the dashed horizontal lines delineate the WMO/GAW measurement compatibility goals.

not deviating more than 0.01 from the mean, and an intercept within 25 per meg of the average. The mean $R^{2}$ was 0.996 .

\subsection{Target measurements}

Target measurements (tanks where the mole fraction all measurands are known but are treated as unknowns) for the time series are presented in Fig. 6. Periods of poorer performance are associated with inadequate electricity supply, dust events, and/or degraded temperature control of the laboratory or a specific instrument. The target tank had to be changed several times during the first 6 months of operation due twice to the loss of target gas during power outages before a more robust power-down procedure was implemented. In the new procedure, after power loss the control computer returns all valves to a configuration that prevents the loss of gas while running on an uninterrupted power supply (UPS) system. Other target tank changes were due to the necessity of switching which tanks served as target and which as working secondary standards as the calibration scheme was adjusted to conserve gas before more cylinders could be delivered. Bias (mean offset) between the assigned values obtained from MPI-BGC
Table 4. Target tank biases (mean of NDAO target measurements assigned value from MPI-BGC).

\begin{tabular}{lrrrrr}
\hline Tank & $\begin{array}{r}\mathrm{CO}_{2} \\
(\mathrm{ppm})\end{array}$ & $\begin{array}{r}\mathrm{CH}_{4} \\
(\mathrm{ppb})\end{array}$ & $\begin{array}{r}\mathrm{N}_{2} \mathrm{O} \\
(\mathrm{ppb})\end{array}$ & $\begin{array}{r}\mathrm{CO} \\
(\mathrm{ppb})\end{array}$ & $\begin{array}{r}\delta\left(\mathrm{O}_{2} / \mathrm{N}_{2}\right) \\
(\text { per meg })\end{array}$ \\
\hline $\mathrm{D} 417492$ & -0.38 & -0.20 & -0.61 & -0.91 & -6.4 \\
$\mathrm{D} 417437$ & -0.01 & -0.70 & 0.26 & -0.06 & -9.8 \\
$\mathrm{D} 417479$ & 0.01 & -0.96 & -0.03 & -1.37 & 3.7 \\
$\mathrm{D} 417471$ & 0.04 & -0.19 & 0.07 & 0.44 & -7.5 \\
$\mathrm{D} 417455$ & 0.04 & 0.05 & 0.08 & 0.74 & -3.0 \\
\hline
\end{tabular}

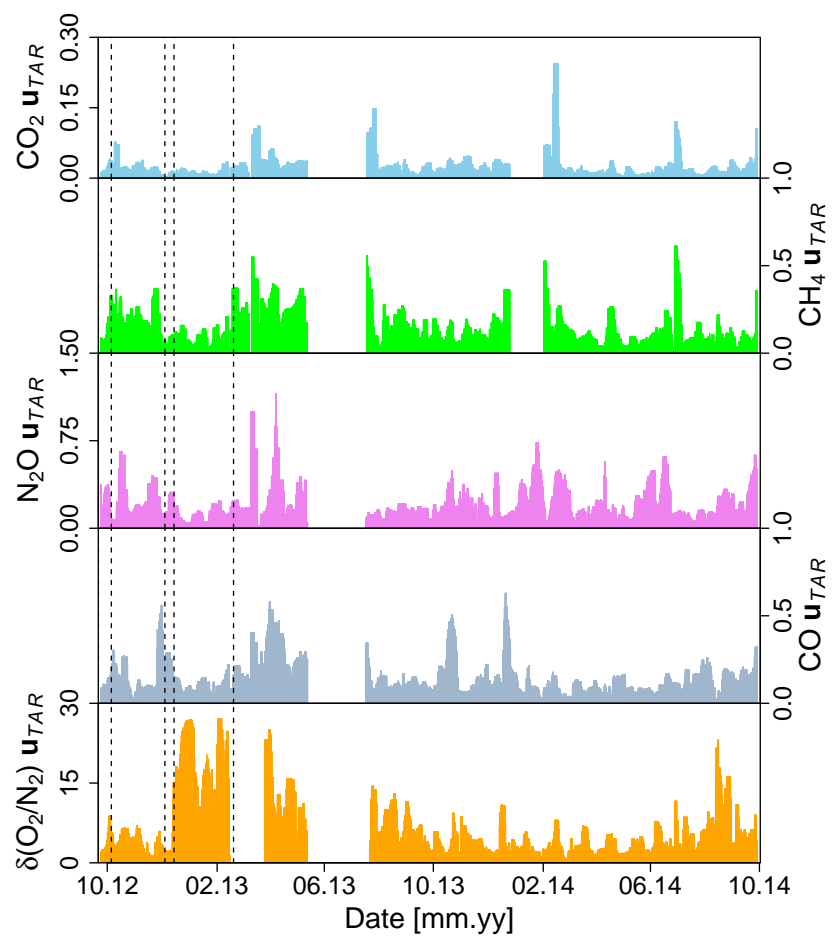

Figure 7. Measurement uncertainty derived from target measurements $\left(\boldsymbol{u}_{\mathrm{TAR}}\right)$. Mean bias (i.e., differences from MPI-BGC determinations of target tank mole fraction from NDAO's determination) for each tank has been removed to better approximate the sample uncertainty (see Table 4). Dashed vertical lines indicate a target tank change.

laboratories of reference tanks and the average of all target measurements at NDAO are given in Table 4.

For oxygen this bias is large enough to warrant some speculation. As the target gas shares the same plumbing lines as the calibration gases, a leak or fractionation effect is unlikely, since it would effect the calibration gases as well. It is always possible that the target was contaminated during installation due to blowback when installing the regulator, which might account for the slightly enhanced $\mathrm{CO}_{2}$ and $\mathrm{CO}$ and the depleted $\delta\left(\mathrm{O}_{2} / \mathrm{N}_{2}\right)$, while $\mathrm{N}_{2} \mathrm{O}$ and $\mathrm{CH}_{4}$ are unaffected as this is the sort of profile one would expect in the laboratory environment. The slope of the linear fit to the calibration data is 

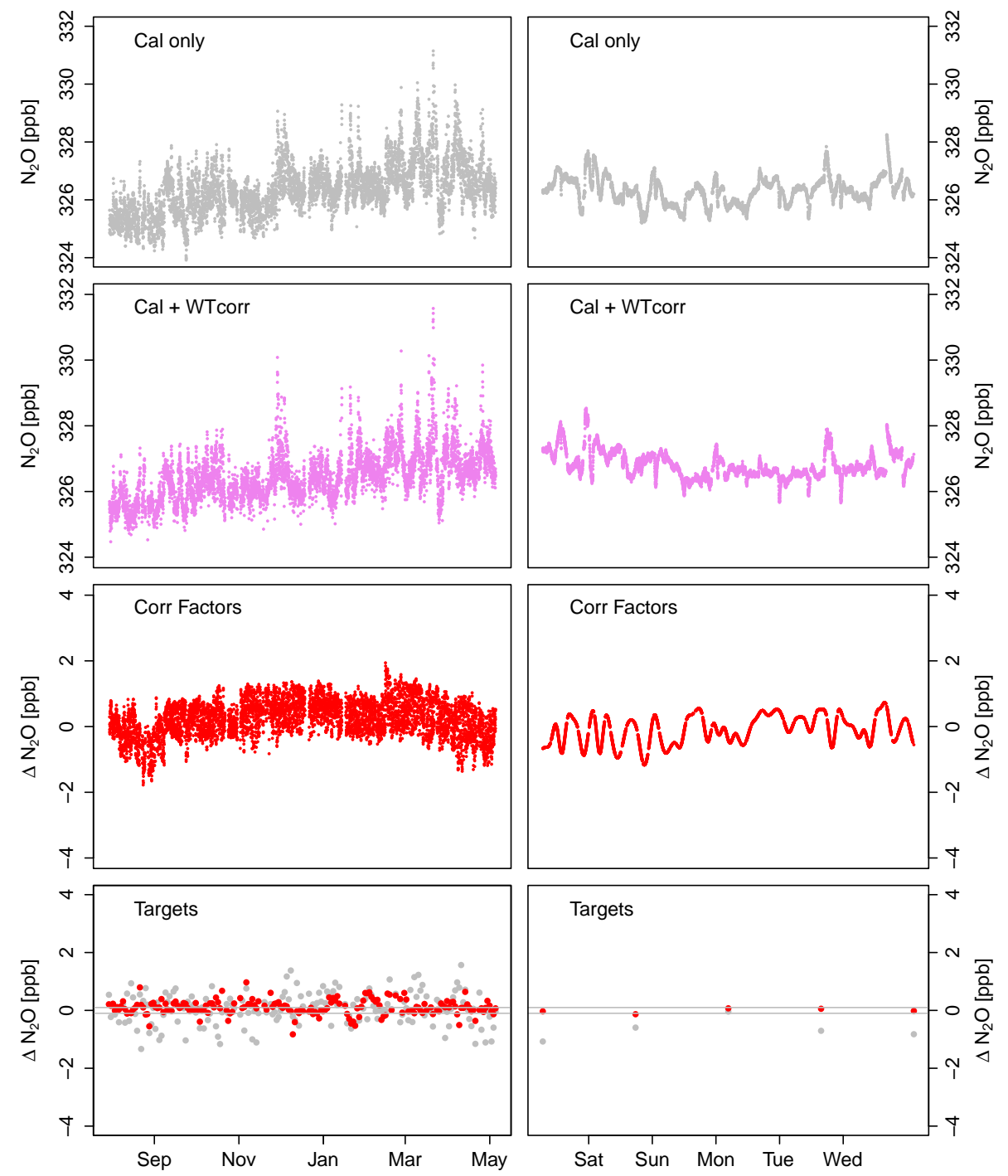

Figure 8. Detail of the working tank correction for the OA-ICOS instrument, showing the correction process for the entire time series (left) and an arbitrarily selected week (right) for $\mathrm{N}_{2} \mathrm{O}$ only. In the first row, $\mathrm{N}_{2} \mathrm{O}$ is shown with only calibrations applied ("Cal only"). In the second row, a drift correction based on the working tank measurements has been applied to the calibrated data ("Cal + WTcorr"). In the third row, the correction factors that were used to produce the data in the second panel are shown ("Corr Factors"). These are determined by calculating the difference between each working tank measurement and the average of all working tank measurements and fitting a curve to groups of consecutive working tank measurements with no gaps (i.e., every $2 \mathrm{~h}$ ). In the fourth panel, target measurements ("Targets") are shown using the calibrated only data (grey points) and the drift corrected and calibrated data (red points).

also quite sensitive to the absolute value of the cylinder with the lowest mole fractions, so these small biases could also be due to inter-laboratory differences at the low end of the scale for those three species.

Measurement uncertainty was estimated from the target tank time series $\left(\boldsymbol{u}_{\mathrm{TAR}}\right)$ to give a time-varying quantity (Fig. 7). The average bias of each target tank was removed to calculate the measurement uncertainty since this varied from tank to tank and would not necessarily impinge on sample uncertainty of the in situ data. Note that this bias was not removed from the target tank time series in Fig. 6.
The mean uncertainty for each species was $0.027 \mathrm{ppm}$ for $\mathrm{CO}_{2}, 0.16 \mathrm{ppb}$ for $\mathrm{CH}_{4}, 0.22 \mathrm{ppb}$ for $\mathrm{N}_{2} \mathrm{O}, 0.15 \mathrm{ppb}$ for $\mathrm{CO}$, and 6.7 per meg for $\delta\left(\mathrm{O}_{2} / \mathrm{N}_{2}\right)$.

\subsection{Drift correction of the OA-ICOS}

The average drift correction over each $2 \mathrm{~h}$ period for the $\mathrm{N}_{2} \mathrm{O}$ data was $\pm 0.47 \mathrm{ppb}$ (or $0.2 \mathrm{ppbh}^{-1}$ ), with a maximum of $\pm 1.9 \mathrm{ppb}$. The corrections for $\mathrm{CO}$ were a little lower, with an average of $\pm 0.31 \mathrm{ppb}$ (or $0.16 \mathrm{ppb} \mathrm{h}^{-1}$ ) and a maximum of $\pm 1.1 \mathrm{ppb}$. The application of this empirical drift correction significantly improved the data quality for both species as 


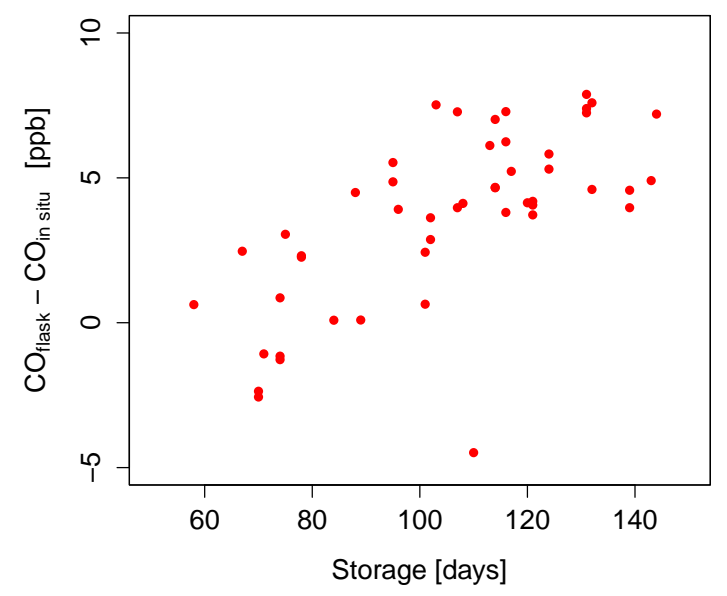

Figure 9. Evidence for a carbon monoxide storage-related artifact. $\mathrm{CO}_{\text {flask }}$ is the average flask measurement, $\mathrm{CO}_{\text {insitu }}$ is the corresponding average of the continuous measurements from the OAICOS. The difference between the two determinations is plotted as a function of storage time from sampling to measurement.

measured through the target cylinders (Fig. 8). In the case of $\mathrm{N}_{2} \mathrm{O}$, this allowed for the performance goal for this species to be reached on average.

\subsection{External validation}

A small inter-laboratory comparison was performed with the global GAW station run by the South African Weather Service at Cape Point, South Africa. A cylinder of dry background air from Cape Point was measured at both sites for $\mathrm{CO}_{2}, \mathrm{CH}_{4}, \mathrm{~N}_{2} \mathrm{O}$, and $\mathrm{CO}$. The absolute value of the difference between the final determinations, i.e., the compatibility, was $0.1,1.2,1.3$, and $0.2 \mathrm{ppb}$, respectively. More comparisons are planned.

Flask samples also offer a kind of external validation of the in situ measurements through assessing the compatibility of the flask and continuous data. The flask time series begins in mid-2013 and is ongoing. The average standard deviation of the flask triplicates were $0.04 \mathrm{ppm}$ for $\mathrm{CO}_{2}, 1.6 \mathrm{ppb}$ for $\mathrm{CH}_{4}$, $0.06 \mathrm{ppb}$ for $\mathrm{N}_{2} \mathrm{O}, 1.1 \mathrm{ppb}$ for $\mathrm{CO}, 4.0$ per meg for $\delta\left(\mathrm{O}_{2} / \mathrm{N}_{2}\right)$, and 3.9 per meg for APO.

Measurement compatibility between flask and in situ measurements is given in Table 2. After accounting for differences in flow rates, the final $10 \mathrm{~min}$ of the $15 \mathrm{~min}$ filling procedure was averaged to compare to the flasks. Most of the bias seen between flask and in situ measurements can be explained for carbon monoxide. CO mole fractions are known to increase in flasks during storage (Novelli et al., 1998; Brenninkmeijer et al., 2001). At MPI-BGC, tests showed rates between 0.02 and $0.03 \mathrm{ppbday}^{-1}$, in some cases as high as $0.05 \mathrm{ppbday}^{-1}$ (A. Jordan, personal communication, 2014). Additionally, the offset showed some dependency on storage time (Fig. 9); the specific mechanism is unknown.

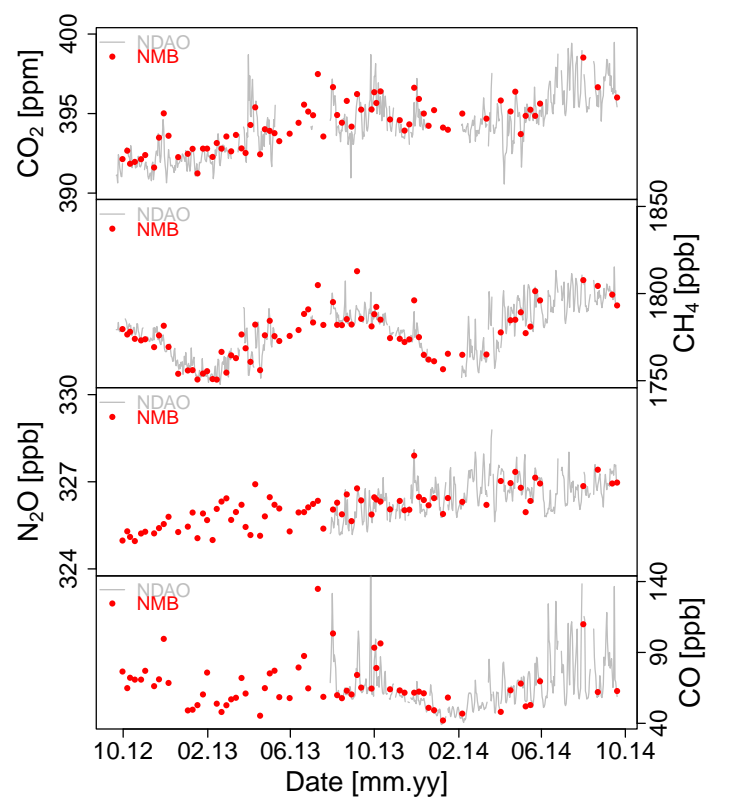

Figure 10. NDAO in situ measurements compared to NMB (NOAA) flask measurements. NDAO values are hourly averages matching the NOAA time of sampling (grey line), NMB values are averages of flask pairs (red circles). Flagged values from the NOAA data set have been excluded, but preliminary data are included.

Additionally, the NDAO in situ time series was compared to the available data set from the nearby NOAA ESRL GMD sampling site NMB (Fig. 10). It should be noted that this is not a direct assessment of the compatibility between the two measurement programs, since the two stations do not really measure the same air masses at exactly the same time; the sites are about $2 \mathrm{~km}$ apart and have a height differential of $32 \mathrm{~m}$. This can be of consequence since the boundary layer oscillations in the local wind field often create considerable heterogeneity in flow, resulting in spatial and temporal gradients of trace gases (Lindesay and Tyson, 1990). While small differences between concurrent measurements at the two sites would be expected, the synoptic variability, seasonality, and long-term trend should be the same, and this is what is observed (for a discussion of these broader trends, see Sect. 3.11). After excluding outliers smaller than $3 \sigma$, the average absolute difference of all concurrent measurements (using $1 \mathrm{~h}$ means for the in situ data) was $0.43 \mathrm{ppm}$ for $\mathrm{CO}_{2}$, $2.4 \mathrm{ppb}$ for $\mathrm{CH}_{4}, 0.25 \mathrm{ppb}$ for $\mathrm{N}_{2} \mathrm{O}$, and $3.4 \mathrm{ppb}$ for $\mathrm{CO}$.

\subsection{Time series}

The full station time series consists of the five main measurands, plus atmospheric potential oxygen (APO), presented in Fig. 11. Six meteorological parameters are also measured continuously, presented in Fig. 12. The time series has been filtered based on diagnostic data and for extreme outliers. 


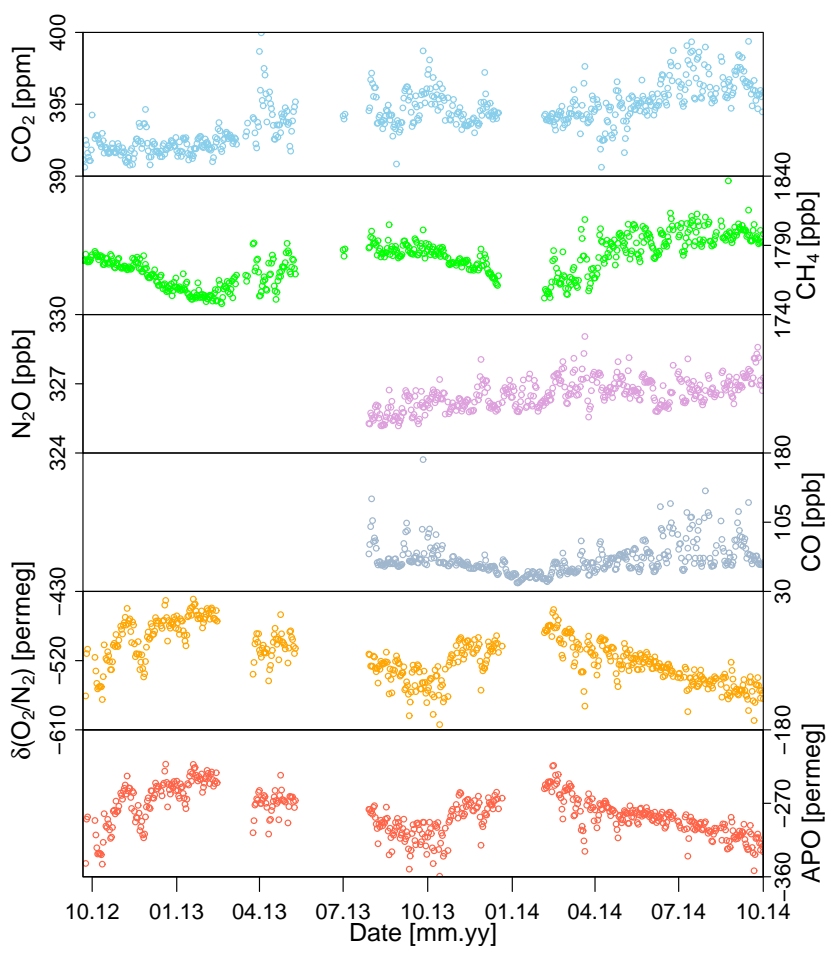

Figure 11. Main time series from NDAO, plotted as daily averages.

Since the aim of this paper is to present and evaluate measurement techniques from the field, we do not provide a detailed scientific analysis of the data but instead briefly characterize the variability of the data with respect to other measurements from the Southern Hemisphere as a final assessment of measurement accuracy.

Annual growth rates for measurands were determined for NDAO, the nearby NOAA ESRL flask site NMB, the observatory run by the South African Weather Service at Cape Point (CPT), and NOAA ESRL flask data for Cape Grim (CGO). The growth rate for NDAO $\mathrm{CO}_{2}$ between October 2012 and October 2013 was $2.9 \mathrm{ppm} \mathrm{yr}^{-1}$ and $1.6 \mathrm{ppm} \mathrm{yr}^{-1}$ for the period October 2013-October 2014. Since the data sets were of different lengths, comparisons were made between sites for identical time periods. For the period October 2012-December 2013, the growth rate of $\mathrm{CO}_{2}$ was $3.0 \mathrm{ppmyr}^{-1}$ for $\mathrm{NMB}$ and $2.9 \mathrm{ppm} \mathrm{yr}^{-1}$ for NDAO, CGO, and CPT. The latter value was the average global growth rate of $\mathrm{CO}_{2}$ for the calendar year 2013 (WMO/GAW, 2014).

For the same period (October 2012-December 2013) the growth rate of methane was determined to be $12.9 \mathrm{ppb} \mathrm{yr}^{-1}$ for NDAO, 11.1 for NMB, 12.3 for CPT, and 10.3 for CGO. During October 2013-October 2014, the growth rate was $16.9 \mathrm{ppbyr}^{-1}$ at NDAO. Some of this discrepancy is due to the short time span and low frequency of sampling, which makes the calculation sensitive to outliers and intraseasonal variability. The average global increase during 2013 was

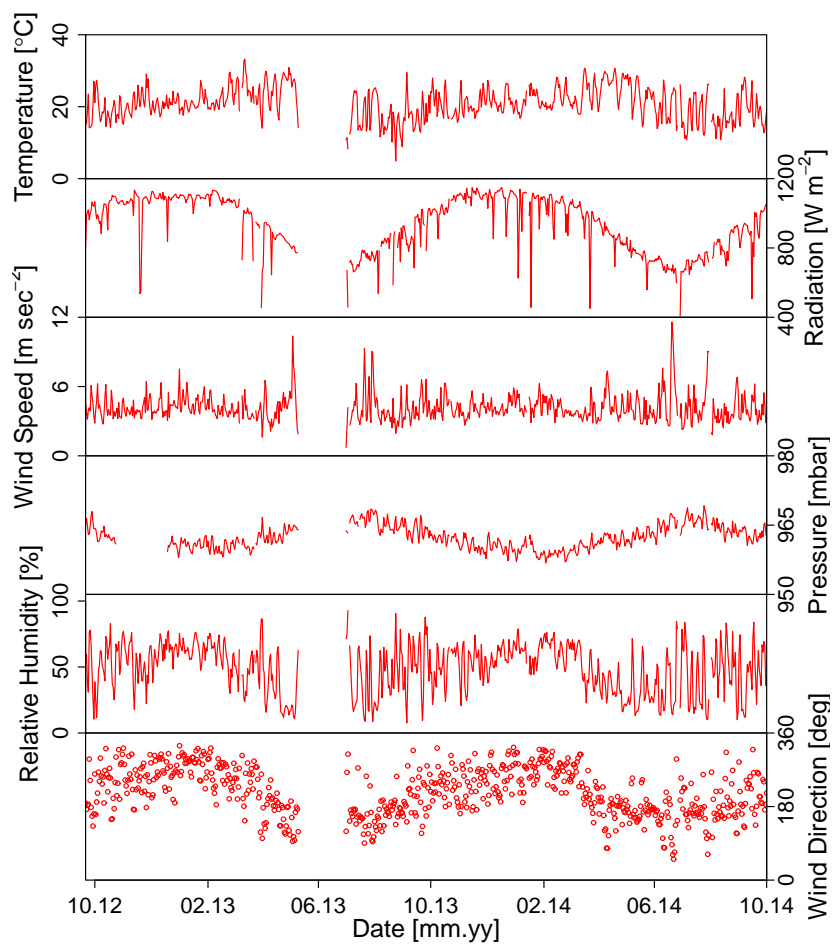

Figure 12. Meteorological time series from NDAO, plotted as daily averages except for solar radiation, which is plotted as a daily maximum value.

$6 \mathrm{ppbyr}^{-1}$ (WMO/GAW, 2014). Growth rates of methane vary with location and latitude (Langenfelds et al., 2002; Dlugokencky et al., 1994), so these higher growth rates could be a result of a larger source of $\mathrm{CH}_{4}$ from the Southern Hemisphere for this year.

Atmospheric growth rates of $\mathrm{N}_{2} \mathrm{O}$ were only obtained for the two sites with sufficiently overlapping time series at the time of writing, NMB and NDAO. The period considered was July 2013-October 2014. At NMB the growth rate was $0.9 \mathrm{ppbyr}^{-1}$ and at NDAO the value was $1.0 \mathrm{ppbyr}^{-1}$.

Seasonality is apparent in the meteorological time series, although in the case of air temperature, the diurnal and synoptic variability masks much of the small seasonal cycle. Wind direction also exhibits some distinct seasonality, with predominately westerly winds (from the ocean) during austral summer and easterly winds during austral winter.

All measurands also display the expected seasonality and generally agree well in phasing and amplitude to the other Southern Hemisphere sites. For $\mathrm{CO}_{2}$ and $\mathrm{CO}$, the seasonal cycle is somewhat distorted, likely due to seasonal changes in atmospheric transport (evident in the seasonality of atmospheric pressure, water vapor, and wind direction) at this site which bring continental air masses to the station during austral winter. This variability is also seen in the NMB data. 


\section{Conclusions}

Generally we find that our gas handling, instrumentation, and conservative reference gas scheme perform acceptably. Using water corrections in lieu of drying is feasible but complicates calibrations and target measurements as the gas lines switch between dry and humidified air. The reduction in maintenance, gas handling complexity, and drying related artifacts, however, make this approach preferable in our judgment.

The differential fuel cell analyzer is a successful approach to the challenge of measuring atmospheric oxygen in a remote location. We find the CRDS to be quite robust and stable. The OA-ICOS instrument gives good performance if instrument drift can be corrected for with a working tank.

NDAO is not totally impervious to the harsh environment, notably dust and heat, and the whole system is sensitive to the large diurnal temperature variation. Most challenging was the inadequate electricity supply, which reduced temperature control in the laboratory, and destroyed two hard drives. Overall, when basic requirements for laboratory operation are met, the measurement system presented can yield much-needed data from a remote and sometimes harsh location.

Acknowledgements. The authors wish to express their gratitude to Gillian Maggs-Kölling, Theo Wassenaar, Mary Seely, Machel Boch, and the Gobabeb community for their support and hospitality. We also thank Walter Holch, for his technical assistance and advice, and Josef Gariseb, Jeffrey Khurisab, Richardt Swartboi, and Samuell Gowaseb for their hard work during the construction of the station. Jörg Reith of MPI-BGC provided valuable assistance as an electrician during the construction of the laboratory. We thank Christian König of MPI-BGC for his help in arranging for the shipment of supplies to and from Gobabeb. Ralph Keeling of Scripps Institution of Oceanography provided helpful comments on a draft of the manuscript. The authors gratefully acknowledge the efforts and expertise of Armin Jordan, Willi Brand, Michael Hielscher, Bert Steinberg, Johannes Schwarz, and Jürgen Richter in preparing and analyzing flask samples and gas cylinders. Bruce Vaughn, Ed Dlugokencky, Paul Novelli, and Tom Conway of NOAA ESRL kindly provided data from the NMB flask sampling site. E. J. Morgan is a part of the International Max Planck Research School for Global Biogeochemical Cycles and acknowledges its funding and support. Funding for the activities detailed in this work was provided by the Max Planck Society.

The article processing charges for this open-access publication were covered by the Max Planck Society.

Edited by: M. von Hobe

\section{References}

Andrews, A. E., Kofler, J. D., Trudeau, M. E., Williams, J. C., Neff, D. H., Masarie, K. A., Chao, D. Y., Kitzis, D. R., Novelli, P. C., Zhao, C. L., Dlugokencky, E. J., Lang, P. M., Crotwell, M. J., Fischer, M. L., Parker, M. J., Lee, J. T., Baumann, D. D., Desai, A. R., Stanier, C. O., De Wekker, S. F. J., Wolfe, D. E., Munger, J. W., and Tans, P. P.: CO2, CO, and CH4 measurements from tall towers in the NOAA Earth System Research Laboratory's Global Greenhouse Gas Reference Network: instrumentation, uncertainty analysis, and recommendations for future high-accuracy greenhouse gas monitoring efforts, Atmos. Meas. Tech., 7, 647-687, doi:10.5194/amt-7-647-2014, 2014.

Arévalo-Martínez, D. L., Beyer, M., Krumbholz, M., Piller, I., Kock, A., Steinhoff, T., Körtzinger, A., and Bange, H. W.: A new method for continuous measurements of oceanic and atmospheric $\mathrm{N}_{2} \mathrm{O}, \mathrm{CO}$ and $\mathrm{CO}_{2}$ : performance of off-axis integrated cavity output spectroscopy (OA-ICOS) coupled to nondispersive infrared detection (NDIR), Ocean Sci., 9, 1071-1087, doi:10.5194/os-9-1071-2013, 2013.

Baer, D., Paul, J., Gupta, M., and O'Keefe, A.: Sensitive absorption measurements in the near-infrared region using off-axis integrated-cavity-output spectroscopy, Applied Physics B, 75, 261-265, doi:10.1007/s00340-002-0971-z, 2002.

Battle, M., Mikaloff Fletcher, S., Bender, M., Keeling, R., Manning, A., Gruber, N., Tans, P., Hendricks, M., Ho, D., Simonds, C., Mika, R., and Paplawsky, B.: Atmospheric potential oxygen: New observations and their implications for some atmospheric and oceanic models, Global Biogeochem. Cy., 20, GB1010, doi:10.1029/2005GB002534, 2006.

Bender, M., Tans, P., Ellis, J., Orchardo, J., and Habfast, K.: A high precision isotope ratio mass spectrometry method for measuring the $\mathrm{O}_{2} / \mathrm{N}_{2}$ ratio of air, Geochimica et Cosmochimica Acta, 58, 4751-4758, 1994.

Blomquist, B. W., Fairall, C. W., Huebert, B. J., and Wilson, S. T.: Direct measurement of the oceanic carbon monoxide flux by eddy correlation, Atmos. Meas. Tech., 5, 3069-3075, doi:10.5194/amt-5-3069-2012, 2012.

Brenninkmeijer, C., Koeppel, C., Röckmann, T., Scharffe, D., Braünlich, M., and Gros, V.: Absolute measurements of the abundance of atmospheric carbon monoxide, J. Geophys. Res., 106, 10003-10010, 2001.

Chen, H., Winderlich, J., Gerbig, C., Hoefer, A., Rella, C. W., Crosson, E. R., Van Pelt, A. D., Steinbach, J., Kolle, O., Beck, V., Daube, B. C., Gottlieb, E. W., Chow, V. Y., Santoni, G. W., and Wofsy, S. C.: High-accuracy continuous airborne measurements of greenhouse gases $\left(\mathrm{CO}_{2}\right.$ and $\left.\mathrm{CH}_{4}\right)$ using the cavity ringdown spectroscopy (CRDS) technique, Atmos. Meas. Tech., 3, 375-386, doi:10.5194/amt-3-375-2010, 2010.

Chen, H., Karion, A., Rella, C. W., Winderlich, J., Gerbig, C., Filges, A., Newberger, T., Sweeney, C., and Tans, P. P.: Accurate measurements of carbon monoxide in humid air using the cavity ring-down spectroscopy (CRDS) technique, Atmos. Meas. Tech., 6, 1031-1040, doi:10.5194/amt-6-1031-2013, 2013.

Crosson, E.: A cavity ring-down analyzer for measuring atmospheric levels of methane, carbon dioxide and water vapor, Applied Physics B, 92, 403-408, 2008.

Dlugokencky, E., Steele, L., Lang, P., and Masarie, K.: The growth rate and distribution of atmospheric methane, J. Geophys. Res., 99, 17021-17043, 1994. 
Flowers, B. A., Powers, H. H., Dubey, M. K., and McDowell, N. G.: Inter-comparison of two high-accuracy fast-response spectroscopic sensors of carbon dioxide: a case study, Atmos. Meas. Tech., 5, 991-997, doi:10.5194/amt-5-991-2012, 2012.

Gruber, N., Gloor, M., Fan, S.-M., and Sarmiento, J.: Air-sea flux of oxygen estimated from bulk data: Implications for the marine and atmospheric oxygen cycles, Global Biogeochem. Cy., 15, 783803, 2001

Hutchinson, P.: The climatology of Namibia and its relevance to the drought situation, in: Coping with Aridity, 17-37, Namibia Economic Policy Research Unit (NEPRU), Brandes \& Apsel, Frankfurt am Main, Germany, 1995.

Jiang, X., Ku, W., Shia, R.-L., Li, Q., Elkins, J., Prinn, R., and Yung, Y.: Seasonal cycle of $\mathrm{N}_{2} \mathrm{O}$ : Analysis of data, Global Biogeochem. Cy., 21, GB1006, doi:10.1029/2006GB002691, 2007.

Keeling, R. and Manning, A.: Studies of Recent Changes in Atmospheric $\mathrm{O}_{2}$ Content, in: Treatise on Geochemistry, edited by: Holland, H. and Turekian, K., Elsevier, Amsterdam, the Netherlands, 5.15, 385-405, 2014.

Keeling, R. and Shertz, S.: Seasonal and interannual variations in atmospheric oxygen and implications for the global carbon cycle, Nature, 358, 723-727, 1992.

Keeling, R., Piper, S., and Heimann, M.: Global and hemispheric $\mathrm{CO}_{2}$ sinks deduced from changes in atmospheric $\mathrm{O}_{2}$ concentration, Nature, 381, 218-221, 1996.

Keeling, R., Manning, A., McEvoy, E., and Shertz, S.: Methods for measuring changes in atmospheric $\mathrm{O}_{2}$ concentration and their application in southern hemisphere air, J. Geophys. Res., 103, 3381-3397, 1998a.

Keeling, R., Stephens, B., Najjar, R., Doney, S., Archer, D., and Heimann, M.: Seasonal variations in the atmospheric $\mathrm{O}_{2} / \mathrm{N}_{2}$ ratio in relation to the kinetics of air-sea gas exchange, Global Biogeochem. Cy., 12, 141-163, 1998b.

Kottek, M., Grieser, J., Beck, C., Rudolf, B., and Rubel, F.: World Map of the Köppen-Geiger climate classification updated, Meteorologische Zeitschrift, 15, 259-263, 2006.

Kozlova, E., Manning, A., Kisilyakhov, Y., Seifert, T., and Heimann, M.: Seasonal, synoptic, and diurnal-scale variability of biogeochemical trace gases and $\mathrm{O}_{2}$ from a 300-m tall tower in central Siberia, Global Biogeochem. Cy., 22, GB4020, doi:10.1029/2008GB003209, 2008.

$\mathrm{Ku}$, A.: Investigation: Is Your SSD More Reliable Than a Hard Drive?, available at: http://www.tomshardware.com/reviews/ ssd-reliability-failure-rate,2923.html (last access: 25 January 2014), 2011.

Lancaster, J., Lancaster, N., and Seely, M.: Climate of the central Namib desert, Madoqua, 14, 5-61, 1984.

Land, D., Levick, A., and Hand, J.: The use of the Allan deviation for the measurement of the noise and drift performance of microwave radiometers, Meas. Sci. Technol., 18, 1917-1928, 2007.

Langenfelds, R., Francey, R., Pak, B., Steele, L., Lloyd, J., Trudinger, C., and Allison, C.: Interannual growth rate variations of atmospheric $\mathrm{CO}_{2}$ and its $\delta^{13} \mathrm{C}, \mathrm{H}_{2}, \mathrm{CH}_{4}$, and $\mathrm{CO}$ between 1992 and 1999 linked to biomass burning, Global Biogeochem. Cy., 16, 1048, doi:10.1029/2001GB001466, 2002.

Lin, J. C., Gerbig, C., Wofsy, S. C., Andrews, A. E., Daube, B. C., Davis, K. J., and Grainger, C. A.: A near-field tool for simulating the upstream influence of atmospheric observations: The
Stochastic Time-Inverted Lagrangian Transport (STILT) model, J. Geophys. Res., 108, 4493, doi:10.1029/2002JD003161, 2003.

Lindesay, J. and Tyson, P.: Thermo-topographically Induced Boundary Layer Oscillations Over the Central Namib, Southern Africa, Int. J. Climat., 101, 63-77, 1990.

Manning, A. and Keeling, R.: Global oceanic and land biotic carbon sinks from the Scripps atmospheric oxygen flask sampling network, Tellus, 58B, 95-116, 2006.

Manning, A., Keeling, R., and Severinghaus, J.: Precise atmospheric oxygen measurements with a paramagnetic oxygen analyzer, Global Biogeochem. Cy., 13, 1107-1115, 1999.

Marquis, M. and Tans, P.: Carbon Crucible, Science, 320, 460-461, 2012.

Nara, H., Tanimoto, H., Tohjima, Y., Mukai, H., Nojiri, Y., Katsumata, K., and Rella, C. W.: Effect of air composition $\left(\mathrm{N} 2, \mathrm{O} 2, \mathrm{Ar}\right.$, and $\mathrm{H} 2 \mathrm{O}$ ) on $\mathrm{CO}_{2}$ and $\mathrm{CH}_{4}$ measurement by wavelength-scanned cavity ring-down spectroscopy: calibration and measurement strategy, Atmos. Meas. Tech., 5, 2689-2701, doi:10.5194/amt-5-2689-2012, 2012.

Novelli, P., Masarie, K., and Lang, P.: Distributions and recent changes of carbon monoxide in the lower troposphere, J. Geophys. Res., 103, 19015-19033, 1998.

Olivier, J. and Stockton, P.: The influence of upwelling extent upon fog incidence at Lüderitz, southern Africa, Int. J. Climatol., 9, 69-75, 1989 .

Olson, D., Dinerstein, E., Wikramanayake, E., Burgess, N., Powell, G., Underwood, E., D'amico, J., Itoua, I., Strand, H., Morrison, J., Loucks, C., Allnutt, T., Ricketts, T., Kura, Y., Lamoreux, J., Wettengel, W., Hedao, P., and Kassem, K.: Terrestrial Ecoregions of the World: A New Map of Life on Earth, BioScience, 51, 933 938, 2001.

O'Shea, S. J., Bauguitte, S. J.-B., Gallagher, M. W., Lowry, D., and Percival, C. J.: Development of a cavity-enhanced absorption spectrometer for airborne measurements of $\mathrm{CH}_{4}$ and $\mathrm{CO}_{2}$, Atmos. Meas. Tech., 6, 1095-1109, doi:10.5194/amt-6-1095-2013, 2013.

Paldus, B. and Kachanov, A.: An historical overview of cavityenhanced methods, Can. J. Physics, 83, 975-999, 2005.

Park, S., Croteau, P., Boering, K., Etheridge, D., Ferretti, D., Fraser, P., Kim, K.-R., Krummel, P., Langenfelds, R., van Ommen, T., Steele, L., and Trudinger, C.: Trends and seasonal cycles in the isotopic composition of nitrous oxide since 1940, Nat. Geosci., 5, 261-265, 2012.

Paul, J., Lapson, L., and Anderson, J.: Ultrasensitive absorption spectroscopy with a high-finesse optical cavity and off-axis alignment, Appl. Opt., 40, 4904-4910, doi:10.1007/s00340-0020971-z, 2001.

Peltola, J., Vainio, M., Siltanen, M., Metsälä, M., and Halonen, L.: Off-axis re-entrant cavity ring-down spectroscopy with a mid-infrared continuous-wave optical parameter oscillator, Appl. Phys. B, 107, 839-847, doi:10.1007/s00340-012-5074-x, 2012.

Rella, C. W., Chen, H., Andrews, A. E., Filges, A., Gerbig, C., Hatakka, J., Karion, A., Miles, N. L., Richardson, S. J., Steinbacher, M., Sweeney, C., Wastine, B., and Zellweger, C.: High accuracy measurements of dry mole fractions of carbon dioxide and methane in humid air, Atmos. Meas. Tech., 6, 837-860, doi:10.5194/amt-6-837-2013, 2013.

Rödenbeck, C., Houweling, S., Gloor, M., and Heimann, M.: $\mathrm{CO}_{2}$ flux history 1982-2001 inferred from atmospheric data using a 
global inversion of atmospheric transport, Atmos. Chem. Phys., 3, 1919-1964, doi:10.5194/acp-3-1919-2003, 2003.

Rödenbeck, C., Quéré, L., Heimann, M., and Keeling, R.: Interannual variability in oceanic biogeochemical processes inferred by inversion of atmospheric $\mathrm{O}_{2} / \mathrm{N}_{2}$ and $\mathrm{CO}_{2}$ data, Tellus, 60B, 685705, 2008.

Severinghaus, J.: Studies of the terrestrial $\mathrm{O}_{2}$ and carbon cycles in sand dune gases and in Biosphere 2, $\mathrm{PhD}$ thesis, Columbia University, USA, 1995.

Shanyengana, E., Henschel, J., Seely, M., and Sanderson, R.: Exploring fog as a supplementary water source in Namibia, Atmos. Res., 64, 251-259, 2002.

Siraya, T.: Comparison of uncertainty estimates: Allan variance and sample variance, Meas. Sci. Rev., 1, 25-28, 2001.

Stephens, B., Keeling, R., Heimann, M., Six, K., Murnane, R., and Caldeira, K.: Testing global ocean carbon cycle models using measurements of atmospheric $\mathrm{O}_{2}$ and $\mathrm{CO}_{2}$ concentration, Global Biogeochem. Cy., 12, 213-230, 1998.

Stephens, B., Keeling, R., and Paplawsky, W.: Shipboard measurements of atmospheric oxygen using a vacuum-ultraviolet absorption technique, Tellus B, 55, 857-878, 2003.

Stephens, B., Bakwin, P., Tans, P., Teclaw, R., and Baumann, D.: Application of a Differential Fuel-Cell Analyzer for Measuring Atmospheric Oxygen Variations, J. Atmos. Ocean. Technol., 24, 82-93, 2007.

Sturm, P., Leuenberger, M., Sirignano, C., Neubert, R., Meijer, H., Langenfelds, R., Brand, W., and Tohjima, Y.: Permeation of atmospheric gases through polymer O-rings used in flasks for air sampling, J. Geophys. Res., 109, D04309, doi:10.1029/2003JD004073, 2004.

Tans, P., Bakwin, P., and Guenther, D.: A feasible Global Carbon Cycle Observing System: a plan to decipher today's carbon cycle based on observations, Glob. Change Biol., 2, 309-318, 1996.

Thompson, R., Manning, A., Lowe, D., and Weatherburn, D.: A ship-based methodology for high precision atmospheric oxygen measurements and its application in the Southern Ocean region, Tellus, 59, 643-653, 2007.

Thompson, R. L., Manning, A. C., Gloor, E., Schultz, U., Seifert, T., Hänsel, F., Jordan, A., and Heimann, M.: In-situ measurements of oxygen, carbon monoxide and greenhouse gases from Ochsenkopf tall tower in Germany, Atmos. Meas. Tech., 2, 573591, doi:10.5194/amt-2-573-2009, 2009.
Tohjima, Y.: Method for measuring changes in the atmospheric $\mathrm{O}_{2} / \mathrm{N}_{2}$ ratio by a gas chromatograph equipped with a thermal conductivity detector, J. Geophys. Res., 105, 14575-14584, doi:10.1029/2004JD005595, 2000.

Tohjima, Y., Machida, T., Watai, I., Akama, T., and Moriwaki, Y.: Preparation of gravimetric standards for measurements of atmospheric oxygen and reevaluation of atmospheric oxygen concentration, J. Geophys. Res., 110, D11302, doi:10.1029/2004JD005595, 2005.

Valentini, R., Arneth, A., Bombelli, A., Castaldi, S., Cazzolla Gatti, R., Chevallier, F., Ciais, P., Grieco, E., Hartmann, J., Henry, M., Houghton, R. A., Jung, M., Kutsch, W. L., Malhi, Y., Mayorga, E., Merbold, L., Murray-Tortarolo, G., Papale, D., Peylin, P., Poulter, B., Raymond, P. A., Santini, M., Sitch, S., Vaglio Laurin, G., van der Werf, G. R., Williams, C. A., and Scholes, R. J.: A full greenhouse gases budget of Africa: synthesis, uncertainties, and vulnerabilities, Biogeosciences, 11, 381-407, doi:10.5194/bg11-381-2014, 2014.

Winderlich, J., Chen, H., Gerbig, C., Seifert, T., Kolle, O., Lavrič, J. V., Kaiser, C., Höfer, A., and Heimann, M.: Continuous lowmaintenance $\mathrm{CO}_{2} / \mathrm{CH}_{4} / \mathrm{H}_{2} \mathrm{O}$ measurements at the Zotino Tall Tower Observatory (ZOTTO) in Central Siberia, Atmos. Meas. Tech., 3, 1113-1128, doi:10.5194/amt-3-1113-2010, 2010.

WMO/GAW: GAW Report No. 213, 17th WMO/IAEA Meeting on Carbon Dioxide, Other Greenhouse Gases and Related Tracers Measurement Techniques (GGMT-2013), Beijing, China, 10-13 June 2013.

WMO/GAW: WMO Greenhouse Gas Bulletin: The State of Greenhouse Gases in the Atmosphere Based on Global Observations through 2013, 9 September, World Meteorological Organization, Geneva, Switzerland, No. 10, 2014.

Zellweger, C., Steinbacher, M., and Buchmann, B.: Evaluation of new laser spectrometer techniques for in-situ carbon monoxide measurements, Atmos. Meas. Tech., 5, 2555-2567, doi:10.5194/amt-5-2555-2012, 2012. 